Article

\title{
Evaluation of the Influencing Factors on Job Satisfaction Based on Combination of PLS-SEM and F-MULTIMOORA Approach
}

\author{
Abteen Ijadi Maghsoodi ${ }^{1, *(1)}$, Iman Azizi-ari ${ }^{1}$, Zahra Barzegar-Kasani ${ }^{2}$, Mehdi Azad $^{3}$, \\ Edmundas Kazimieras Zavadskas ${ }^{4}(1)$ and Jurgita Antucheviciene ${ }^{5}$ (i) \\ 1 Department of Industrial Engineering, Science and Research Branch, Islamic Azad University, \\ Tehran 1477893855, Iran; imanazizi65@gmail.com \\ 2 Department of Management, Central Tehran Branch, Islamic Azad University, Tehran 1477893855, Iran; \\ zahrabarzegar18@yahoo.com \\ 3 Department of Humanities, Faculty of Humanities and Psychology, Shahid Chamran University, \\ Ahvaz 6135743136, Iran; azadmehdi@ymail.com \\ 4 Institute of Sustainable Construction, Vilnius Gediminas Technical University, LT-10223 Vilnius, Lithuania; \\ edmundas.zavadskas@vgtu.lt \\ 5 Department of Construction Management and Real Estate, Vilnius Gediminas Technical University, \\ LT-10223 Vilnius, Lithuania; jurgita.antucheviciene@vgtu.lt \\ * Correspondence: aimaghsoodi@srbiau.ac.ir; Tel.: +98-912-643-3448
}

Received: 6 December 2018; Accepted: 24 December 2018; Published: 28 December 2018

check for updates

\begin{abstract}
A primary issue that is being discussed nowadays in organizations is continuous improvement of the organization itself, because the procedure of periodic evaluation is an important tool to maintain the improvement of the organization. An essential factor in any organization is the human resources as a key asset to guide organizations to sustain their competitive advantages by employing particular knowledge and skills to form a comprehensive and sustainable human resource management. Evaluation of job satisfaction has become a part of the strategic approach toward incorporating business policies and human resource actions in modern day organizations. The current research study presents a novel hybrid validation framework to evaluate and appraise the factors influencing job satisfaction based on the fuzzy MULTIMOORA approach and partial least-squares path modeling (PLS-PM). The proposed fuzzy MCDM technique and statistical method validate each other to present an optimal assessment of influencing factors in job satisfaction. Eventually, a real-world case study in regard to influential factors in job satisfaction has been suggested in this study, to show that the proposed framework is a practical and accurate method to tackle an assessment problem in a real-world application of influencing factors in job satisfaction in a cross-industrial multi-national construction and geotechnical engineering organization in Iran.
\end{abstract}

Keywords: job satisfaction; modelling in management engineering; sustainable human resource management; structural equation model (SEM); partial least-squares path modeling (PLS-PM); fuzzy multiple criteria decision-making (FMCDM); F-MULTIMOORA

\section{Introduction}

In today's competitive and dynamic atmosphere in organizations all around the world, satisfaction is one of the important issues that have been through a huge paradigm shift in the definition. Satisfaction has been defined in many different ways. "Fulfilment of a need or want", "a source or means of enjoyment" and "the quality or state of being satisfied" are defined in Webster dictionary, however, these are only a few of the definitions of satisfaction. Locke [1] described job satisfaction as a 
positive feeling and emotional attitude of individuals against their current job and employment status. Spector [2] described job satisfaction as a general feeling about the job or as a related set of attitudes and approaches about different aspects of the job and employment status.

Job satisfaction is one of the most widely overviewed concepts that has been investigated in an industrial/organizational psychology research context, and hundreds of definitions of job satisfaction have been made since this day [3]. There are various variables and elements that can influence job satisfaction such as job salary, organization environment, and type of work activity. In this study, the significance of various factors for job satisfaction has been analyzed based on a real-world investigation of the job satisfaction concept. Before analyzing the effect of each factor on job satisfaction, an assessment of proposed variables was obtained. Whenever the subject of evaluation and ranking about a subject is discussed, one of the best solutions is Multiple Criteria Decision-Making (MCDM). These techniques are one of the popular methodologies which can help decision-makers rank their evaluation and assessment problems. The implication of MCDM methods in human resource management activities has been studied widely in the past few years [4-6].

The current research study is focused on investigating the effects of multiple independent factors influencing job satisfaction. The first phase of this study is a presentation of an MCDM methodology for evaluating factors affecting job satisfaction in order to measure the importance of each criterion. To achieve this target, after the determination of independent factors from experts comments and previous research, the Multi-Objective Optimization on the basis of Ratio Analysis plus the full multiplicative form (MULTIMOORA) has been implied based on a fuzzy data structure. In the second phase, after evaluating the effect of each factor on job satisfaction, a calculation of elements influencing the job satisfaction has been obtained by utilizing the Structural Equation Model (SEM). Ultimately, based on the proposed approaches and techniques, a real-world case study has been analyzed in a cross-industrial multinational company in Iran.

The current paper is structured as the following. Section 2.1 overviews a short survey on job satisfaction developments. Section 2.2 presents a short survey on applications and developments on MULTIMOORA approach. Section 2.3 discusses research gaps and contributions of the current research. Section 3 overviews the research methodology. Section 4 presents the application of the proposed framework in a real-world case study as well as finding and managerial discussions of the proposed case study, while Section 5 offers conclusions and recommendations for the further research.

\section{Research Background and Literature Overview}

\subsection{Survey on Job Satisfaction and Proposed Evaluations}

Job satisfaction is one of the most important direct measurements of effectiveness in order to obtain the productivity of employees considering their current jobs which concerns the continuous improvement [7]. Presumed job satisfaction has an enormous amount of behavioral consequences and huge concerns of various factors. Since job satisfaction has been introduced in the human resources literature, it has been theorized and applied by psychologists, organizational scientist, and management experts. Many theoretical frameworks and real-world applications and developments have been suggested in this regard. Metle [8] proposed an exploration of the relationship between job satisfaction and educational factors considering the field of education and the level of education in a private banking sector among Kuwaiti women employees utilizing need fulfillment theory and Herzberg's two-factor theory. Moreover, there are many studies which have analyzed the relationship between the institutional factors and job satisfaction $[9,10]$.

Hann et al. [11] performed a secondary data analysis with a view to obtaining the relationship amongst job satisfaction, intentions to leave family practice and actually leaving among family physicians in the National Health Service (NHS) in Britain. Mansor et al. [12] analyzed with a view to investigating the job satisfaction among bankers in the Islamic financial institution in the eastern region of Malaysia. Elshout et al. [13] suggested a consolidated method design with quantitative and 
qualitative research structure to analyze the link between leadership style, employment satisfaction, and absenteeism in a mental health care institution in the Netherlands. Ruchman et al. [14] evaluated the job satisfaction of the Accreditation Council for Graduate Medical Education (ACGME)-approved diagnostic radiology programs. Frey et al. [15] proposed an experimental study and a dyadic field study to measure the influence of customer satisfaction on employee satisfaction and retention in professional services at two western European business schools, in which students are in business administration. Naqbi et al. [16] identified the evaluation factors of employee satisfaction with services of Human Resources (HR) Departments in the Fujairah Medical District (FMD) in the UAE.

Tansel and Gazîoğlu [17] investigated the job satisfaction considering managerial attitudes concerning employees and firm size in Britain. Matthies-Baraibar et al. [18] measured the employee satisfaction considering organizational development in the implementation of the European Foundation for Quality Management (EFQM) model in 30 healthcare organizations including hospitals, primary care and mental health providers in Osakidetza. Tso et al. [19] suggested an exploratory research on identifying elements influencing employee satisfaction in Chinese resource-based state-owned enterprises. Leder et al. [20] presented a measurement to assess the effect of office environment on employee satisfaction considering open-plan and private offices. Mathieu et al. [21] proposed an evaluation of the relationship between supervisory behavior, job satisfaction and organizational commitment to employee turnover in small and medium-sized enterprises as well as large enterprises. Jacobs et al. [22] explored the influence of internal communication and employee satisfaction on supply chain integration in China.

Barakat et al. [23] presented a measurement in order to evaluate the effect of corporate social responsibility on employee satisfaction in Brazil. Boddy and Taplin [24] investigated the relationship between job satisfaction and workplace psychopathy factor. Koklic et al. [25] suggested an examination of customer satisfaction with low-cost and full-service airline companies. Tarcan et al. [26] presented an assessment of the connection between burnout and job satisfaction among emergency health professionals in emergency services in two public hospitals in Turkey. Holmberg et al. [27] applied the two-factor theory in order to evaluate job satisfaction among Swedish mental health nursing personnel. Bae and Yang [28] proposed an assessment of the influential factors of family-friendly policies in job satisfaction and organizational commitment in Korea. Hafez et al. [29] examined the effect of talent management on employee retention and job satisfaction for personnel administration at Ain-Shams University in Egypt.

Hayes et al. [30] presented a comprehensive review of literature of factors contributing to nursing job satisfaction which was conducted between 2004 and 2009 to identify elements contributing to satisfaction for nurses working in acute hospital settings. Zhu [31] overviewed the concept of job satisfaction and the influential factors for the proposed concept in a-decade period. Furthermore, Hantula [32] suggested a literature review on job satisfaction and influencing factors. Özpehlivan and Acar [3] proposed and validated a multidimensional job satisfaction scale in different cultures which has been collected from well-known Turkish and Russian people in the business.

\subsection{Survey on Applications and Developments on the MULTIMOORA Method}

The multi-objective optimization on the basis of ratio analysis plus the full multiplicative form (MULTIMOORA) method is an efficient and robust technique that has been proposed by Brauers and Zavadskas [33]. The MULITMOORA method is established based on four phases, including three subordinate techniques and one dominant theory that combines the three subordinate ranks. This methodology has proven to be more robust and accurate ranks than traditional MADM methods and its previous structure, MOORA method. The robustness of the MULTIMOORA approach has been investigated for the first time by Brauers and Zavadskas [34] in a project management problem. Since the introduction of the MULTIMOORA approach, many research studies have utilized this methodology in various decision-making and evaluation problems. 
Balezentis and Balezentis [35] suggested a comprehensive survey on the extensions of MULTIMOORA approach based on the fuzzy environment and group decision-making. Zavadskas et al. [36] suggested a novel extension of the MULTIMOORA method by combining interval-valued intuitionistic fuzzy terms. Stanujkic et al. [37] suggested the extended MULTIMOORA approach based on a triangular fuzzy data set in order to solve a communication circuits design selection problem. Awasthi and Baležentis [38] presented a combinative methodology using BOCR criteria integrated with F-MULTIMOORA approach based on a Monte Carlo simulation sensitivity analysis, in order to determine the robustness of the proposed method to variation in criterion and decision-maker weights in a logistics service provider selection. Stanujkic et al. [39] suggested an extended MULTIMOORA method integrated with single-valued neutrosophic terms that was resulted as an efficient methodology in terms of solving complex predictive problems. The extension was applied by Zavadskas et al. [40]. Gou et al. [41] presented an application of the MULTIMOORA approach combined with a hesitant fuzzy linguistic structure as well as a double-hierarchy hesitant fuzzy linguistic structure in a selection of the optimal city in China with evaluation of the implementation status of haze controlling measures.

Ceballos et al. [42] proposed a comparison of rankings calculated by F-MULTIMOORA, F-TOPSIS, F-VIKOR, and F-WASPAS to answer the primary question which occurs in every MCDM problem, which is "which method should be used to solve the ranking problem", and the result of this question is still open. Stević et al. [43] applied a hybrid novel MCDM methodology including DEMATEL, EDAS, COPRAS and MULTIMOORA methods in a supplier selection problem in regard to a construction organization. Maghsoodi et al. [44] suggested an application of the MULTIMOORA approach integrated with Shannon's entropy in ranking and selecting the best performance appraisal method in an organization in Iran. Maghsoodi et al. [45] proposed a combinative approach called cluster analysis for improving multiple criteria decision analysis (CLUS-MCDA) including the k-means clustering technique and MULTIMOORA method in order to tackle a big data supplier selection problem in an ICT company in Iran. Hafezalkotob et al. [46] presented a hybrid decision support system based on a combination of BWM approach with target-based MULTIMOORA and WASPAS applied in an olive harvester machines and equipment selection problem. Chen et al. [47] applied the MULTIMOORA method along with linguistic evaluations in order to form a multi-attribute group decision-making method which was applied in a wastewater treatment assessment problem.

\subsection{Research Gap and Contributions of the Current Study}

There are many studies that have analyzed and investigated the influencing factors on job satisfaction. In almost all of the previous studies regarding the factors influencing job satisfaction, no more than four factors have been analyzed at the same time. Additionally, to the best of the authors' knowledge, no single study has considered a framework based on a fuzzy MCDM approach combined with a statistical approach alongside. Ultimately, no single research study has conducted an MCDM approach in an assessment and evaluation problem regarding influencing factors of job satisfaction. Specifically, there is not a single study that shows an application of the F-MULTIMOORA method in an evaluation considering influencing elements of job satisfaction, which means the current study proposed a novel application of the F-MULTIMOORA method in order to assess the influential factors of job satisfaction and to validate a statistical method along with multiple other contributions. The focus of this paper is to provide a framework based on an F-MULTIMOORA approach, and PLS-SEM-based CFA, in order to evaluate the influence measurement of each factor affecting job satisfaction with respect to nine factors. In this study, in order to present a clear image of the procedure, a real-world case study has been utilized which is a cross-industrial multinational company in Iran. A questionnaire has been made by the researchers and experts in the mentioned organization to gather the related data of computation in statistical phase. To be fairly concise, the current research study presents a comprehensive proposition of a practical application considering consolidation of a fuzzy MCDM method and a statistical approach to validate both approaches in a real-world organization problem. 


\section{Research Methodology}

\subsection{F-MULTIMOORA Approach}

Brauers and Zavadskas [33] developed the multi-objective optimization by ratio analysis (MOORA) which was composed from the combination of the ratio system and the reference point approach, later on, the full multiplicative form added to the MOORA technique in order to form an extended version of the MOORA approach, called MULTIMOORA method which is a more robust procedure for ranking and assessment of similar complex problems [34]. The F-MULTIMOORA approach has been suggested by Brauers et al. [48] that has been implied in the current study. A feasible solution to tackle the uncertainty in the modeling problems is the implication of the fuzzy sets and fuzzy logic. Zadeh [49] presented and developed the fuzzy set theory as an extension of the classical set theory due to the uses of natural language application of the exact data, which is impossible in real-world problems. The current study utilized a triangular fuzzy number (TFN). It should also be noted that while using such data structure can be useful for utilizing fuzzy sets, there are also other approaches that can be utilized with MADM approaches. For example, utilization of adaptive neuro-fuzzy system can be very useful in projection and prediction of decision-making problems [50-53].

Consequently, the fuzzy set theory can be employed on these specified problems considering uncertain environments. The first phase in the F-MULTIMOORA approach is forming the fuzzy decision matrix $\widetilde{X}$, where $\widetilde{x}_{i j}=\left(x_{i j 1}, x_{i j 2}, x_{i j 3}\right)$ presents the performance index of $i^{\text {th }}$ alternative respecting $j^{\text {th }}$ attribute $i=1,2, \ldots, m$ and $j=1,2, \ldots, n$, and the $\widetilde{x}_{i j}$ values are aggregated by using a fuzzy weighted averaging (FWA) operator, i.e. Equation (2), where $\widetilde{\Psi}_{k}$ denotes the fuzzy coefficient of significance for the $k^{\text {th }}$ decision-maker:

$$
\begin{gathered}
X=\left[\widetilde{x}_{i j}\right]_{m \times n^{\prime}} \\
\widetilde{x}_{i j}=\frac{\sum_{k=1}^{K} \widetilde{\Psi}_{k} \widetilde{x}_{i j}^{k}}{\sum_{k=1}^{K} \widetilde{\Psi}_{k}},
\end{gathered}
$$

The calculation parameters of the F-MULTIMOORA technique have to be without dimensions in order to compare the performance indices. Consequently, the fuzzy decision matrix is a normalization ratio based on a comparison amongst responses of an alternative to a criterion as a numerator, and a denominator that is a representative for all alternative performances on that attribute. The dimension dominator is performed by comparing the appropriate values of fuzzy numbers:

$$
\tilde{x}_{i j}^{*}=\left(\tilde{x}_{i j 1}^{*}, \tilde{x}_{i j 2}^{*}, \tilde{x}_{i j 3}^{*}\right)=\left(\frac{x_{i j 1}}{\sqrt{\sum_{i=1}^{m} x_{i j 1}^{2}}}, \frac{x_{i j 2}}{\sqrt{\sum_{i=1}^{m} x_{i j 2}^{2}}}, \frac{x_{i j 3}}{\sqrt{\sum_{i=1}^{m} x_{i j 3}^{2}}}\right), \text { for all } i, j,
$$

where $\widetilde{x}_{i j}^{*}$ signifies the normalized performance index of $i^{\text {th }}$ alternative with respect to $j^{\text {th }}$ attribute $i=1,2, \ldots, m$ and $j=1,2, \ldots, n$. The proposed normalization approach is the most robust selection among various normalization methods considering the F-MULTIMOORA technique

\subsubsection{The Fuzzy Ratio System}

In the current assessment and selection approach, the fuzzy normalization structure, i.e., Equation (3), justifies the foundations of F-MULTIMOORA method as the fuzzy ratio system, and the fuzzy normalized performance indices are added in case of maximization and subtracted in the event of minimization according to mathematical calculations between fuzzy values:

$$
\widetilde{y}_{i}^{*}=\sum_{j=1}^{g} \widetilde{x}_{i j}^{*} \ominus \sum_{j=g+1}^{n} \widetilde{x}_{i j}^{*}
$$


where $g$ represents the objectives being maximized, $(n-g)$ indicates the objectives being minimized, and $\widetilde{y}_{i}^{*}$ shows the total fuzzy assessment of alternative $i$ which can be positive or negative based on the totals of calculations. Each ratio $\widetilde{y}_{i}^{*}=\left(\widetilde{y}_{i 1}^{*}, \widetilde{y}_{i 2}^{*}, \widetilde{y}_{i 3}^{*}\right)$ is defuzzified by applying the best non-fuzzy performance value $B N P_{i}$ of the $i^{\text {th }}$ alternative:

$$
B N P_{\widetilde{y}_{i}^{*}}=\left(\frac{\left(\widetilde{y}_{i 3}^{*}-\widetilde{y}_{i 1}^{*}\right)+\left(\widetilde{y}_{i 2}^{*}-\widetilde{y}_{i 1}^{*}\right)}{3}+\widetilde{y}_{i 1}^{*}\right),
$$

The optimal alternative of the fuzzy ratio system $A_{F R S}^{*}$ is an ordinal ranking of the $B N P_{\widetilde{y}_{i}^{*}}$ that has the maximum (or highest) assessment value:

$$
A_{F R S}^{*}=\left\{A_{i} \mid \max _{i} B N P_{\widetilde{y}_{i}^{*}}\right\}
$$

\subsubsection{The Fuzzy Reference Point Approach}

The second phase of the F-MULTIMOORA method is established based on the fuzzy normalization technique, as demonstrated in Equation (3). A maximal fuzzy objective reference point is also included in the method which is obtained as the following:

$$
\widetilde{r}_{j}=\left\{\begin{array}{c}
\widetilde{x}_{j}^{+}=\left(\max _{i} x_{i j 1}^{*}, \max _{i} x_{i j 2}^{*}, \max _{i} x_{i j 3}^{*}\right) \text { in case of maximization }(j \leq g) \\
\widetilde{x}_{j}^{+}=\left(\min _{i} x_{i j 1}^{*}, \min _{i} x_{i j 2}^{*}, \min _{i} x_{i j 3}^{*}\right) \text { in case of minimization }(j>g)
\end{array},\right.
$$

where $\widetilde{r}_{j}$ signifies the $i^{\text {th }}$ co-ordinate of the fuzzy maximal objective reference point vector.

Deviation of a performance index from the reference point $r_{j}$ can be obtained by calculation of the distance between the fuzzy values of $\widetilde{r}_{j}$ and $\widetilde{x}_{i j}^{*}$. Subsequently, the maximum value of the deviation of each alternative $z_{i}^{*}$ can be obtained as follows:

$$
\widetilde{z}_{i}^{*}=\max _{j}\left|d\left(\widetilde{r}_{j}, \widetilde{x}_{i j}^{*}\right)\right|,
$$

Moreover, the optimal alternative $A_{F R P}^{*}$ in the fuzzy reference point method can be calculated by ranking the lowest assessment value $\widetilde{z}_{i}^{*}$ which is demonstrated in Equation (9):

$$
A_{F R P}^{*}=\left\{A_{i} \mid \min _{i} \widetilde{z}_{i}^{*}\right\} .
$$

\subsubsection{The Fuzzy Full Multiplicative Form}

The third phase of the MULTIMOORA approach is extended by Brauers and Zavadskas [34] based on an idea in economic mathematics. Later on, the fuzzy form of the proposed technique was suggested by Brauers et al. [48]. The crisp format of the full multiplicative form can be demonstrated as showed in Equation (10), where g denotes the objectives being maximized and $(n-g)$ indicates the objectives being minimized. The numerator of Equation (10) indicates the product of performance indices of $i^{\text {th }}$ alternative related to beneficial attributes. The denominator of Equation (10) shows the product of performance indices of $i^{\text {th }}$ alternative regarding non-beneficial attributes with respect to the weights of the subjective coefficients $w_{j}^{s}$ (if available):

$$
U_{i}^{\prime}=\frac{\prod_{j=1}^{g}\left(x_{i j}\right)^{w_{j}^{s}}}{\prod_{j=g+1}^{n}\left(x_{i j}\right)^{w_{j}^{s}}}
$$

The overall utility of the $i^{\text {th }}$ alternative can be presented as dimensionless values by employing the division of a fuzzy number in order to form the fuzzy full multiplicative form assessment value:

$$
\widetilde{U}_{i}^{\prime}=\widetilde{A}_{i} \oslash \widetilde{B}_{i}
$$




$$
\begin{aligned}
& \widetilde{A}_{i}=\left(A_{i 1}, A_{i 2}, A_{i 3}\right)=\prod_{j=1}^{g} \widetilde{x}_{i j}^{*}, i=1,2, \ldots m \text { and } g=1,2, \ldots n, \\
& \widetilde{B}_{i}=\left(B_{i 1}, B_{i 2}, B_{i 3}\right)=\prod_{j=g+1}^{n} \widetilde{x}_{i j}^{*}, i=1,2, \ldots m \text { and } g=1,2, \ldots n,
\end{aligned}
$$

where $\widetilde{A}_{i}$ describes the product of objectives of the $i^{\text {th }}$ alternative to be maximized with $g$, being the number of objectives (structural indicators) to be maximized, and $\widetilde{A}_{i}$ denotes the product of objectives of the $i^{\text {th }}$ alternative to be minimized with $n-g$ value being the number of objectives (structural indicators) to be minimized. Each value of $\widetilde{U}_{i}^{* \prime}=\left(\widetilde{U}_{i 1}^{* \prime}, \widetilde{U}_{i 2}^{* \prime}, \widetilde{U}_{i 3}^{* \prime}\right)$ is defuzzified by applying the best non-fuzzy performance value $B N P_{i}$ of the $i^{\text {th }}$ alternative:

$$
B N P_{\widetilde{U}_{i}^{* \prime}}=\left(\frac{\left(\widetilde{U}_{i 3}^{* \prime}-\widetilde{U}_{i 1}^{* \prime}\right)+\left(\widetilde{U}_{i 2}^{* \prime}-\widetilde{U}_{i 1}^{* \prime}\right)}{3}+\widetilde{U}_{i 1}^{* \prime}\right)
$$

The optimal alternative $A_{F M F}^{*}$ in the fuzzy full multiplicative form is obtained based on the searching for the highest value among all assessment values of $B N P_{\widetilde{U}_{i}^{* \prime}}$ as demonstrated:

$$
A_{F M F}^{*}=\left\{A_{i} \mid \max _{i} B N P_{\widetilde{U}_{i}^{* \prime}}\right\} .
$$

\subsubsection{The Dominance Theory}

The dominance theory was developed as a methodology for ranking subordinate alternatives in the MULTIMOORA approach [54,55]. After the computation of each subordinate technique rankings, they can be integrated into a final rank, which is the final result of the MULTIMOORA approach. In dominance theory, a summary of the classification of the three MULTIMOORA methods (which are the fuzzy values in the current study) is made based on cardinal and ordinal scales, where rankings rules should be applied including dominance, transitivity and equability [54]. Theory of dominance can be discussed as: (1) "the plurality rule assisted with a kind of lexicographic method", and (2) "the method of correlation of ranks", which has been described by Brauers and Zavadskas [54]. For a more detailed explanation of the dominance theory, refer to study of Brauers and Zavadskas [54].

\subsection{Structural Equation Modeling (SEM) Based on Partial Least Squares (PLS)}

A popular approach to statistic modeling procedures, which is used in an enormous array of complex modeling areas, is path analysis developed by Wright [56]. Path analysis is one of the special cases of the SEM which is a structure from an extensive set of mathematical and statistical algorithms and models that contains confirmatory factor analysis, path analysis, partial least squares path modeling, and latent growth modeling. In this study, components-based SEM, or partial least squares path modeling (partial least-squares path modeling (PLS-PM) or PLS-SEM) has been utilized that allows calculating complex cause-effect relationship models with latent variables. SEMs are multiple-equation regression models considering the response variable in one regression equation can present an explanatory variable in another equation, which contains two main variables that have effects on each another, reciprocally, directly, or indirectly, considering a feedback loop [57]. On the other hand, SEMs are known as a tool to analyze multivariate problems; this model goes beyond ordinary regression models to subsume multiple independent and dependent variables along with hypothetical latent constructs that clusters of observed variables might represent [58]. A review about applications of SEM to solve sustainability problems is presented [59].

Before describing the SEM procedure and related factors, there are few classes of variables that need to be explained. Starting with endogenous variables $y_{\alpha}$, and $y_{\beta}$ that are the response variables of the model, and exogenous variables $x_{\alpha}$ and $x_{\beta}$, which are determined outside of the model, it means there are only explanatory variables in the structural equations, and structural errors $\varepsilon_{\alpha}$, and $\varepsilon_{\beta}$ denote 
the aggregated omitted causes of the endogenous variables and possibly intrinsic randomness in the endogenous variables. There can be two types of structural coefficients: structural coefficients of an exogenous variable on an endogenous variable which is denoted as $\gamma_{\alpha \alpha}$, and structural coefficients of an endogenous variable on another endogenous variable $\beta_{\alpha \beta}$. The same rules is also applicable for covariance, i.e., two exogenous variables $\sigma_{\alpha \beta}$ and two error variables $\sigma_{\alpha \beta}$. The SEM of a specified model can be read directly from the path diagram but sometimes it is useful (e.g. for generality) to cast a structural-equation model in an equation form, which can be presented as follow:

$$
B_{(n \times n)} y_{i_{(n \times 1)}}+\Gamma_{(n \times m)} x_{i_{(m \times 1)}}=\varepsilon_{i_{(n \times 1)}} .
$$

where there are $n$ endogenous variables, also $n$ errors and $m$ exogenous variables, and $B$ and $\Gamma$ are matrices of structural coefficients.

As mentioned earlier, PLS-PM was applied in the current study. The PLS-PM approach aims to define a system of weights to be applied to each variable, i.e., endogenous or exogenous variables. Optimization criteria behind the PLS-PM approach based on the outward directed links and inward directed links can be written as a general form, which is demonstrated as follows:

$$
\begin{aligned}
& \operatorname{argmax}_{w_{n}}=\left\{\sum_{n \neq m} c_{n m} g\left(\operatorname{cov}\left(x_{n} w_{n}, x_{m} w_{m}\right)\right)\right\}= \\
& \operatorname{argmax}_{w_{n}}=\left\{\sum_{n \neq m} c_{n m} g\left[\operatorname{cor}\left(x_{n} w_{n}, x_{m} w_{m}\right) \sqrt{\operatorname{var}\left(x_{n} w_{n}\right)} \sqrt{\operatorname{var}\left(x_{m} w_{m}\right)}\right\},\right. \\
& \text { st. }\left\|x_{n} w_{n}\right\|^{2},\left\|w_{n}\right\|^{2} \text {. } \\
& \text { where } c_{n m}=\left\{\begin{array}{cc}
0 & \text { if } x_{n} \text { and } x_{m} \text { are conected } \\
1 & \text { otherwide }
\end{array}\right. \\
& g=\left\{\begin{array}{cl}
\text { Square } & \text { Factorial scheme } \\
\text { Abolute Value } & \text { centeroid scheme }
\end{array} .\right.
\end{aligned}
$$

where $w_{n}$ denotes the outer weights of the $n^{\text {th }}$ variable, and $x_{n}$ presents the latent variable. As aforementioned in the current study, a factor analysis is utilized by this study. To be precise, confirmatory factor analysis (CFA) was used; CFA is a form of factor analysis where it is used to test to which extent a construct or a factor is consistent with the proposed understanding of the nature of the mentioned construct or factor. Before applying a CFA, a hypothesis has to be developed which is about the underlying measures of proposed hypothesis; by implying these constraints, the proposition has forced the model to be consistent with the theory [60]. Furthermore, Exploratory Factor Analysis (EFA) determines the nature and number of latent variables that account for observed variation and covariation among a set of observed elements [60]. Two types of CFA output are available in general, which are: (a) unstandardized and (b) standardized versions. The unstandardized form predicts scale-sensitive original item response which is very useful to compare solutions across groups or time, demonstrated in Equation (18). Consequently, when the solution is transformed to $\operatorname{var}\left(y_{i}\right)=1$ and $\operatorname{var}(F)=1$, CFA could be obtained in a standardized form which is useful when comparing items within a solution and on the same scale, measurement model per item $(i=1,2, \ldots n)$ for subject $n$ obtain as follow:

$$
x_{i n}=\mu_{i}+\lambda_{i} F_{n}+\varepsilon_{\text {in }}
$$

where $x_{i n}$ denotes the main component or variable, $\mu_{i}$ is the item's intercept factor, $\lambda_{i}$ is the factor loading, $F_{n}=\operatorname{var}\left(x_{i n}\right)_{n}$ is the factor variance, and $\varepsilon_{i n}$ demonstrates the error variance. To sum up, in the current study, an SEM model based on the PLS-PM (or PLS-SEM) logic has been applied considering CFA reasoning. The suggested approach is a path analysis proposition. Figure 1 illustrates a conceptual SEM considering a PLS path model based on the CFA approach. 


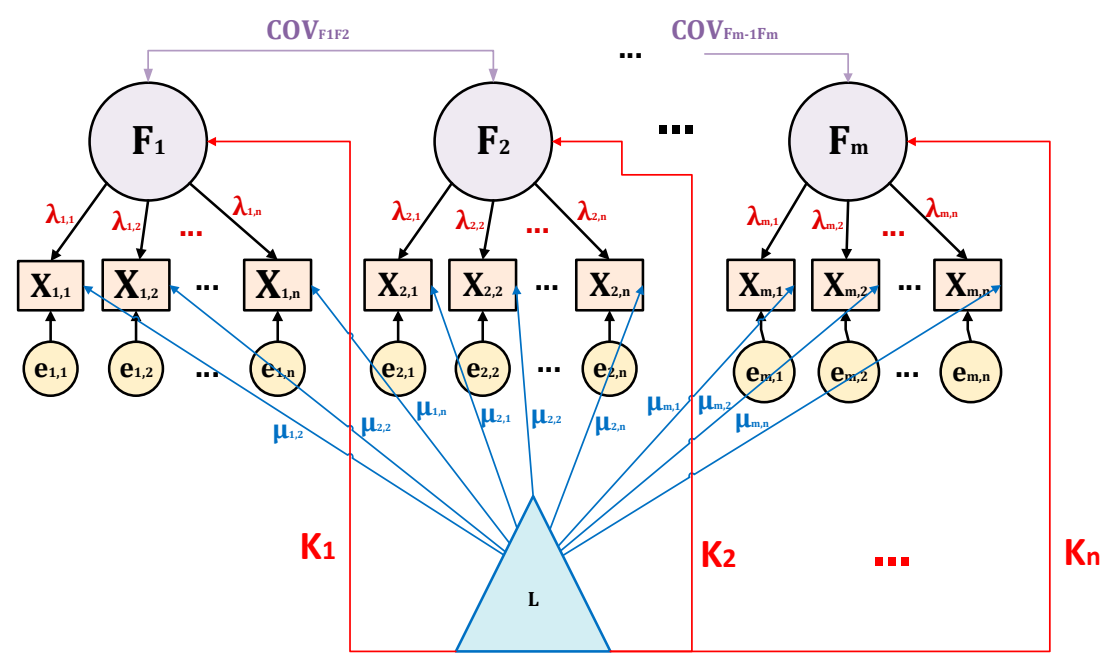

Figure 1. A conceptual CFA model based on PLS-SEM including factor means and item intercepts.

To describe how well the statistical model fits a set of observations (between observed values and the values expected in the model), the global model fit needs to be calculated. Table 1 describes the global model fit indices for SEM-based PLS-SEM considering CFA.

Table 1. Indices of global model fit.

\begin{tabular}{|c|c|c|c|}
\hline Fit Indices & Statistical Notation & Formula & \\
\hline Construct Reliability & CR & $C R=\frac{\sum\left(\lambda_{n, m}\right)^{2}}{\sum\left(\lambda_{n m}\right)^{2}+\sum\left(\operatorname{Var}\left(\varepsilon_{n, m}\right)\right)}$ & (19) \\
\hline Average Variance Extracted & AVE & Ave $=\frac{\sum(\text { Communalities })^{2}}{n}$ & (20) \\
\hline Blindfolding Criteria Index & $\mathrm{F} 2(\mathrm{~A} / \mathrm{B})$ & $F^{2}\left(\frac{A}{B}\right)=\frac{R_{\text {included }}^{2}-R_{\text {excluded }}^{2}}{1-R_{\text {included }}^{2}}$ & (21) \\
\hline Goodness of Fit & GOF & GOF $=\sqrt{\overline{\text { Communality }} * \overline{R^{2}}}$ & $(22)$ \\
\hline Coefficient of Determination & $\mathrm{R} 2$ & $R^{2}=1-\left(\frac{L(0)}{L(\alpha)}\right)^{2 / n}$ & (23) \\
\hline
\end{tabular}

\section{A Case Study: Evaluation of Factors Influencing Job Satisfaction in an Organization}

The type of this study is a practical and validation experiment, regarding its objective as a presentation of a novel procedure in order to evaluate a hybrid framework, i.e., statistical approach and FMCDM technique. However, the proposed algorithm could be also extended based on a specific input data structure in terms of mathematical calculations. Considering the content and data collection, this study is descriptive and quantitative, and the type of review is a real-world case study of an organization in Iran. Given that the success of assessment and evaluation of the influencing factors of job satisfaction in an organization is taken from the perspective of the human resource manager, high-level managers, and strategic management, the study population included the specialists, experts, and officials, which are concerned by the evaluation of the influencing factors of job satisfaction in a multi-national cross-industrial company with the major activities in construction and transportation infrastructure, along with technical consultancy of geotechnical management in Iran.

A set of criteria was collected in order to process the first stage of the current study, which is application of the FMCDM method, i.e. F-MULTIMOORA, in assessing the influencing factors of job satisfaction, which was identified and collected from the previous research and expert comments that are classified in Table 2, in which the description of each criterion is available. Table 3 shows the candidate alternatives, i.e., influencing factors which were selected to be included in the ranking procedure to obtain the degree of importance based on the calculated final ranking. 
Table 2. Criteria definitions for evaluating the influencing factors in job satisfaction.

\begin{tabular}{|c|c|c|c|}
\hline ID & Criteria & Functional Requirement & Description \\
\hline $\mathrm{C} 1$ & Organizational Strategies & Maximum & $\begin{array}{l}\text { The definition and description of job satisfaction could be } \\
\text { different based on the organization's practical strategies, in } \\
\text { which the core concept of job satisfaction is defined in the } \\
\text { organization's predetermined objectives and vision. Therefore, } \\
\text { it is crucial to include the idea of job satisfaction in the } \\
\text { functional strategy. }\end{array}$ \\
\hline $\mathrm{C} 2$ & $\begin{array}{l}\text { Importance of the } \\
\text { Influencing Criteria }\end{array}$ & Maximum & $\begin{array}{l}\text { In order to rank and present a comprehensive assessment of } \\
\text { each influencing factor on job satisfaction in the current study, } \\
\text { instead of using the weighting technique in the MCDM } \\
\text { approach, specific criteria have been assigned in the } \\
\text { ranking procedure. }\end{array}$ \\
\hline C3 & Cost of Improvement & Minimum & $\begin{array}{l}\text { Cost improvement is an important factor in evaluating the } \\
\text { influencing factors in job satisfaction, and is the cost of the } \\
\text { improvement. Because it is critical for every organization to } \\
\text { calculate how much it takes to improve the } \\
\text { specific deficiencies. }\end{array}$ \\
\hline $\mathrm{C} 4$ & $\begin{array}{l}\text { Comprehensiveness of } \\
\text { Criteria (All Levels) }\end{array}$ & Maximum & $\begin{array}{l}\text { To rank the influencing factor in job satisfaction with an } \\
\text { MCDM procedure, it is important to choose the right factors. } \\
\text { This criterion evaluates the measure of the accuracy of the } \\
\text { suggested factor in every job level in the organization. }\end{array}$ \\
\hline C5 & The Degree of Difficulty & Minimum & $\begin{array}{l}\text { The difficulty level of measuring the specific criteria is varied } \\
\text { due to the influencing elements and sub-criteria of specific } \\
\text { factors. Therefore, there might be few sub-criteria which could } \\
\text { have an effect on the proposed factor and make the } \\
\text { measurement difficult. }\end{array}$ \\
\hline C6 & $\begin{array}{l}\text { Fitness of criteria with } \\
\text { maturity level }\end{array}$ & Maximum & $\begin{array}{l}\text { Criteria fitness with the maturity standards of the } \\
\text { organization is one of the main reasons that a factor is selected } \\
\text { among many influencing factors in the job satisfaction in the } \\
\text { previous literature, which is based on the measurements of } \\
\text { the maturity levels of each organization by itself. }\end{array}$ \\
\hline $\mathrm{C} 7$ & $\begin{array}{l}\text { Compatibility with } \\
\text { Organizational }\end{array}$ & Maximum & $\begin{array}{l}\text { If an organization wants to survive or improve in the } \\
\text { competitive environments, the periodic change should take } \\
\text { place. To maintain the satisfaction of the employees, it is } \\
\text { imperative to select the compatible influencing factors in } \\
\text { job satisfaction. }\end{array}$ \\
\hline $\mathrm{C} 8$ & $\begin{array}{l}\text { Comprehensiveness of } \\
\text { Criteria (Project Level) }\end{array}$ & Maximum & $\begin{array}{c}\text { The suggested case study in this research is an organization } \\
\text { which has both the traditional and the project-based structure. } \\
\text { This criterion evaluates the degree of accuracy of the } \\
\text { suggested factor in the project structure job level in } \\
\text { the organization. }\end{array}$ \\
\hline C9 & $\begin{array}{l}\text { Physical and Mental } \\
\text { Health Factors }\end{array}$ & Maximum & $\begin{array}{l}\text { To obtain an accurate evaluation of an influencing factor in the } \\
\text { job satisfaction, it is critical to include the physical and } \\
\text { psychological health setting of the factor in the job satisfaction, } \\
\text { and it is important to select the appropriate factor to maintain } \\
\text { the physical and mental health factors. }\end{array}$ \\
\hline $\mathrm{C} 10$ & Managers Standards & Maximum & $\begin{array}{l}\text { One of the important criteria for evaluating the influencing } \\
\text { factors in job satisfaction is the opinions of the supervisors. } \\
\text { There might be many factors which could have enormous } \\
\text { effects on job satisfaction generally, but there are specific } \\
\text { elements that would have the accuracy to evaluate the job } \\
\text { satisfaction in different organizations. }\end{array}$ \\
\hline
\end{tabular}

Table 3. Influencing factors in job satisfaction, i.e., candidate alternatives for assessment.

\begin{tabular}{crc}
\hline ID & \multicolumn{1}{c}{ Influencing Factor } & Description \\
\hline A1 & Organizational Commitment & $\begin{array}{r}\text { One of the important indicators of advantages in an organization is the } \\
\text { employees' commitment. The more employees are satisfied in an organization, } \\
\text { the more commitment each employee shows in their behavior. Furthermore, } \\
\text { abandonment of employees will have high costs for the organization which can } \\
\text { be prevented by increasing the satisfaction levels of the employees. }\end{array}$ \\
A2 & $\begin{array}{r}\text { From the beginning of the management science, leadership evolves many times. } \\
\text { The method of supervisory is an important factor in maintaining the satisfaction } \\
\text { of employees. By development in technology, the paradigm of the leadership has } \\
\text { been changed and the expectations undergo many changes, which is a significant } \\
\text { factor in improving and implying corrective actions. }\end{array}$ \\
\hline
\end{tabular}


Table 3. Cont.

\begin{tabular}{|c|c|c|}
\hline ID & Influencing Factor & Description \\
\hline A3 & Job Security & $\begin{array}{l}\text { With a view to protecting the employees from fluctuations of wage and salary, } \\
\text { and to keeping the job positions safe, the factor of job security arises. Job security } \\
\text { is a mental aspect which is directly connected to job satisfaction. Consequently, } \\
\text { whenever the job security levels are high, it will have positive results on } \\
\text { job satisfaction. }\end{array}$ \\
\hline A4 & Wage and Salary & $\begin{array}{l}\text { To pay back the labor contribution in any type, wage and salaries have been } \\
\text { raised. One of the significant elements in any organization for any workforce, } \\
\text { in general, is the number of salaries and wage. Ultimately, there are many } \\
\text { employees who are only motivated by the wage and salary factor in achieving } \\
\text { higher job satisfaction. }\end{array}$ \\
\hline A5 & Job Stress & $\begin{array}{l}\text { An important influencing factor in job satisfaction is the level of job stress. } \\
\text { In order to survive in today's dynamic and competitive organizations, an } \\
\text { employee will suffer from an enormous amount of stress. Job stress is one of the } \\
\text { main reasons for the existence of the burnout concept, because there are many } \\
\text { people who are willing to tolerate a high amount of stress in order to maintain a } \\
\text { normal life quality. }\end{array}$ \\
\hline A6 & $\begin{array}{l}\text { Individual Development } \\
\text { Possibility }\end{array}$ & $\begin{array}{l}\text { Personal growth is one of the key issues that a person attends a job position. } \\
\text { A'human being is an ideal creature which is continuously searching for } \\
\text { self-development and possibilities to grow. Therefore, availability of the } \\
\text { individual development possibility in an organization results in structuring a } \\
\text { pleasing environment for the workforce. }\end{array}$ \\
\hline A7 & Amenities & $\begin{array}{l}\text { In order to make positive enforcement in organizations, exclusive services are } \\
\text { offered to employees. The amenities suggested to employees may vary } \\
\text { considering different job positions. Consequently, lack of these specific services } \\
\text { for employees is one of the reasons for abandonment in many organizations. }\end{array}$ \\
\hline A8 & Personnel Relationship & $\begin{array}{l}\text { One of the features of a healthy person is their skills and abilities to communicate } \\
\text { with other people. The work environment, in general, is the second home for } \\
\text { many individuals because they spend most of their adult life in such } \\
\text { environments. Therefore, lack of communication in the workplace results in a } \\
\text { decrease in job satisfaction in general. }\end{array}$ \\
\hline A9 & $\begin{array}{l}\text { Educational and Learning } \\
\text { Opportunity }\end{array}$ & $\begin{array}{l}\text { Availability of learning and educational opportunities is one of the important } \\
\text { factors influencing job satisfaction in general. The reason is that every human } \\
\text { being is searching for an opportunity to develop and grow. Therefore, if in a job } \\
\text { position the educational and learning opportunity is absent, eventually the } \\
\text { situation becomes impractical and purposeless. }\end{array}$ \\
\hline
\end{tabular}

Flyvbjerg [61] suggested that to employ in-depth research on any topic, "one can study only one case, and the result can be generalized." Ultimately, the mentioned case study in this research was not chosen randomly. It intended and targeted to select a specific organization to be able to obtain certain understandings that other organizations would not be able to offer which, in this case study, is collecting an input data, where validation of a statistical model and FMCDM model in a hybrid framework is meaningful. Moreover, expert judgments are valid enough to check the proposition of the mentioned framework. As aforementioned, the present study was structured from two main phases. First, the evaluation process of the influencing factors in job satisfaction was based on the F-MULTIMOORA approach. Second, the assessment procedure of the similar approach utilizd a statistical technique, i.e., PLS-SEM. Consequently, to validate the proposed techniques, a hybrid framework was implied. Ultimately, the final ranking results of the mentioned techniques were compared to the expert judgments in the real-world case study. The comparison was applied using the Spearman's correlation coefficients.

The necessary research data for the current research in this case study in the FMCDM phase were collected through interview using a Question \& Answer (Q\&A) approach based on a linguistic structure presented in Table 4. The primary objective of the Q\&A approach was to complete the decision matrix which builds on the linguistic terms and the corresponding numbers in Table 4 . The statistical approach was obtained by random sampling through a custom researcher-made questionnaire based on a population of $400(\mathrm{~N}=400)$, considering a reliable sample size of $200(S=200)$ concerning on sample size determination through the Krejcie and Morgan table. Characteristics of the respondents in both the statistical approach and FMCDM method regarding their education, occupation, and experience 
are high-level management employees, supervisors, and experts in human resource management. Additionally, the calculation process of the F-MULTIMOORA approach was computed by Microsoft Excel 2013, and in the statistical approach, the input data were processed with IBM SPSS 2015, and the SEM path modeling was computed with the SmartPLS software. To present a better understanding of the proposed validation framework which also evaluates the job satisfaction levels, Figure 2 illustrates a comprehensive discerption of the proposed method.

Table 4. Linguistic terms and the corresponding numbers.

\begin{tabular}{ccc}
\hline Linguistic Term & Alphabetical Value of Verbal Comments & Numerical Value of Verbal Comments \\
\hline Very Poor & VP & $(1,1,1)$ \\
Poor & P & $(1,2,3)$ \\
Moderate & M & $(2,3,4)$ \\
Good & G & $(3,4,5)$ \\
Very Good & VG & $(4,5,6)$ \\
\hline
\end{tabular}

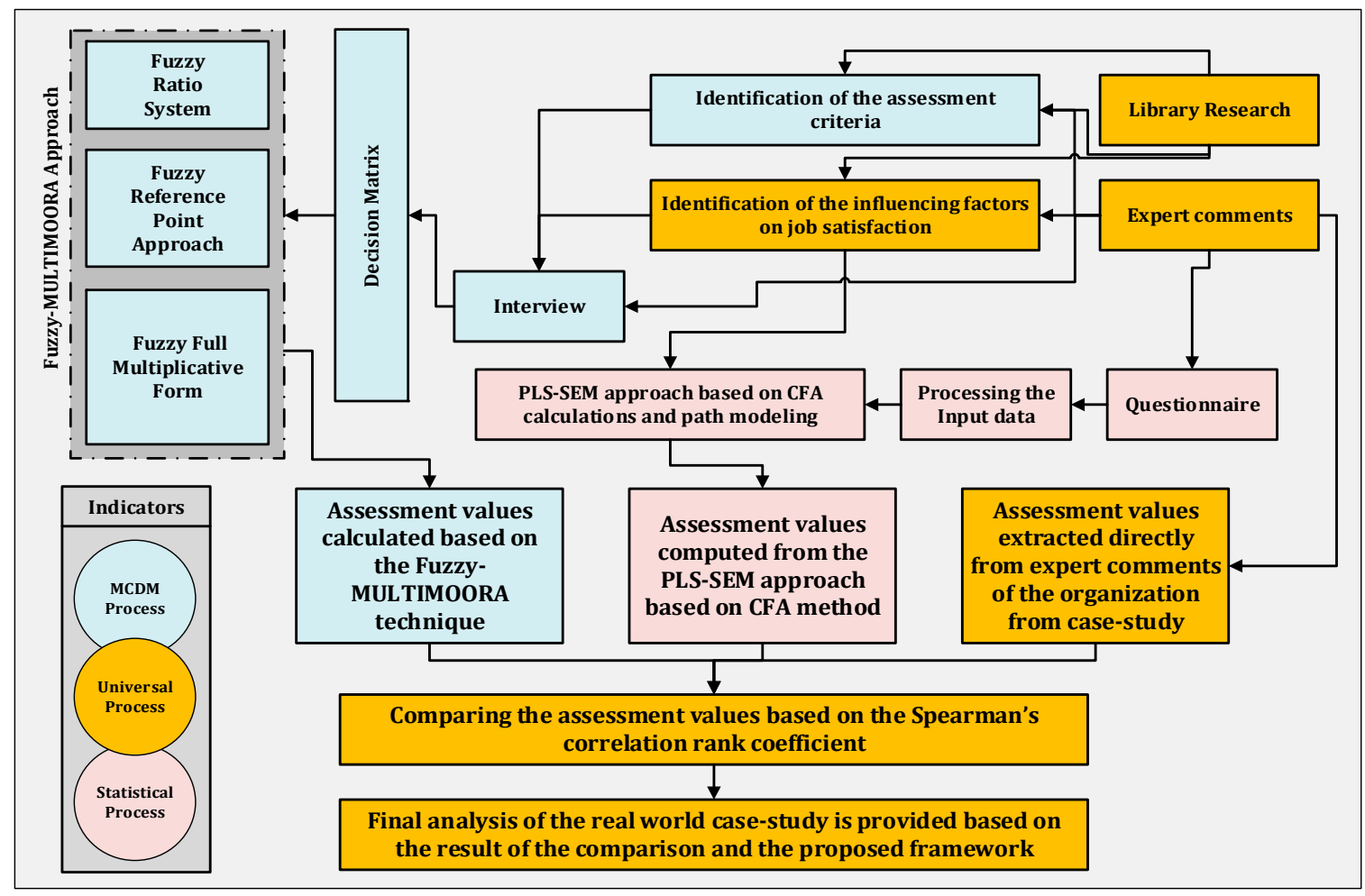

Figure 2. Flow diagram of the evaluation process regarding influencing factors of job satisfaction.

\subsection{Finding and Results}

The current section investigates the usability and accuracy of the proposed methodology that have been introduced in the previous section in a multinational cross-industrial organization in Iran. Accordingly, the fundamental purpose of identifying the alternatives and criteria, along with a linguistic term set that was described in Table 4, was to complete the fuzzy decision matrix based on the numerical values of the linguistic terms, which were obtained and presented in Table 5, based on the assessment criteria and candidate alternatives regarding the influencing job satisfaction factors and elements. 
Table 5. The fuzzy decision matrix to evaluate the influencing factors in job satisfaction.

\begin{tabular}{ccccccccccc}
\hline & \multicolumn{10}{c}{ Criteria } \\
\cline { 2 - 10 } Influencing Factors & $\begin{array}{c}\text { C1 } \\
\text { (Max) }\end{array}$ & $\begin{array}{c}\text { C2 } \\
\text { (Max) }\end{array}$ & $\begin{array}{c}\text { C3 } \\
\text { (Min) }\end{array}$ & $\begin{array}{c}\text { C4 } \\
\text { (Max) }\end{array}$ & $\begin{array}{c}\text { C5 } \\
\text { (Min) }\end{array}$ & $\begin{array}{c}\text { C6 } \\
\text { (Max) }\end{array}$ & $\begin{array}{c}\text { C7 } \\
\text { (Max) }\end{array}$ & $\begin{array}{c}\text { C8 } \\
\text { (Max) }\end{array}$ & $\begin{array}{c}\text { C9 } \\
\text { (Max) }\end{array}$ & $\begin{array}{c}\text { C10 } \\
\text { (Max) }\end{array}$ \\
\hline A1 & $(2,3,4)$ & $(4,5,6)$ & $(3,4,5)$ & $(4,5,6)$ & $(1,1,1)$ & $(3,4,5)$ & $(1,2,3)$ & $(3,4,5)$ & $(1,2,3)$ & $(3,4,5)$ \\
A2 & $(1,2,3)$ & $(2,3,4)$ & $(1,2,3)$ & $(3,4,5)$ & $(3,4,5)$ & $(2,3,4)$ & $(1,2,3)$ & $(2,3,4)$ & $(3,4,5)$ & $(1,2,3)$ \\
A3 & $(4,5,6)$ & $(3,4,5)$ & $(1,2,3)$ & $(4,5,6)$ & $(2,3,4)$ & $(2,3,4)$ & $(3,4,5)$ & $(3,4,5)$ & $(4,5,6)$ & $(1,2,3)$ \\
A4 & $(4,5,6)$ & $(3,4,5)$ & $(2,3,4)$ & $(3,4,5)$ & $(1,2,3)$ & $(3,4,5)$ & $(4,5,6)$ & $(4,5,6)$ & $(4,5,6)$ & $(4,5,6)$ \\
A5 & $(1,2,3)$ & $(3,4,5)$ & $(3,4,5)$ & $(2,3,4)$ & $(3,4,5)$ & $(2,3,4)$ & $(2,3,4)$ & $(1,2,3)$ & $(2,3,4)$ & $(3,4,5)$ \\
A6 & $(4,5,6)$ & $(1,2,3)$ & $(3,4,5)$ & $(1,2,3)$ & $(3,4,5)$ & $(2,3,4)$ & $(3,4,5)$ & $(3,4,5)$ & $(2,3,4)$ & $(3,4,5)$ \\
A7 & $(1,2,3)$ & $(1,1,1)$ & $(3,4,5)$ & $(4,5,6)$ & $(1,2,3)$ & $(3,4,5)$ & $(2,3,4)$ & $(3,4,5)$ & $(4,5,6)$ & $(3,4,5)$ \\
A8 & $(4,5,6)$ & $(1,2,3)$ & $(3,4,5)$ & $(3,4,5)$ & $(3,4,5)$ & $(2,3,4)$ & $(1,2,3)$ & $(2,3,4)$ & $(3,4,5)$ & $(3,4,5)$ \\
A9 & $(4,5,6)$ & $(1,2,3)$ & $(4,5,6)$ & $(3,4,5)$ & $(1,2,3)$ & $(2,3,4)$ & $(2,3,4)$ & $(3,4,5)$ & $(3,4,5)$ & $(2,3,4)$ \\
\hline
\end{tabular}

As mentioned before, to proceed the F-MULTIMOORA process, the decision matrix (which has different dimensions and measurement units) has to transform into a dimensionless matrix. The normalization procedure applied based on Equation (3) dominates the dimensions in the fuzzy decision matrix to compare numbers to each other. The normalized fuzzy decision matrix is demonstrated in Table 6.

Table 6. The normalized fuzzy decision matrix to evaluate the influencing factors in job satisfaction.

\begin{tabular}{|c|c|c|c|c|c|c|c|c|c|c|}
\hline \multirow{2}{*}{ Influencing Factors } & \multicolumn{10}{|c|}{ Criteria } \\
\hline & $\begin{array}{c}\text { C1 } \\
\text { (Max) }\end{array}$ & $\begin{array}{c}\text { C2 } \\
(\mathrm{Max})\end{array}$ & $\begin{array}{c}\text { C3 } \\
\text { (Min) }\end{array}$ & $\begin{array}{c}\text { C4 } \\
\text { (Max) }\end{array}$ & $\begin{array}{c}\text { C5 } \\
\text { (Min) }\end{array}$ & $\begin{array}{c}\text { C6 } \\
\text { (Max) }\end{array}$ & $\begin{array}{c}\text { C7 } \\
\text { (Max) }\end{array}$ & $\begin{array}{c}\text { C8 } \\
\text { (Max) }\end{array}$ & $\begin{array}{c}\text { C9 } \\
\text { (Max) }\end{array}$ & $\begin{array}{c}\text { C10 } \\
\text { (Max) }\end{array}$ \\
\hline A1 & $\begin{array}{c}(0.22, \\
0.25,0.27)\end{array}$ & $\begin{array}{c}(0.56 \\
0.51 \\
0.48)\end{array}$ & $\begin{array}{l}(0.36 \\
0.36 \\
0.35)\end{array}$ & $\begin{array}{l}(0.42 \\
0.40 \\
0.39)\end{array}$ & $\begin{array}{c}(0.15 \\
0.10 \\
0.08)\end{array}$ & $\begin{array}{l}(0.42 \\
0.39 \\
0.38)\end{array}$ & $\begin{array}{l}(0.14 \\
0.20 \\
0.23)\end{array}$ & $\begin{array}{l}(0.35 \\
0.35 \\
0.35)\end{array}$ & $\begin{array}{l}(0.10, \\
0.16, \\
0.20)\end{array}$ & $\begin{array}{l}(0.36, \\
0.36, \\
0.35)\end{array}$ \\
\hline $\mathrm{A} 2$ & $\begin{array}{c}(0.11 \\
0.17 \\
0.20)\end{array}$ & $\begin{array}{c}(0.28 \\
0.30 \\
0.32)\end{array}$ & $\begin{array}{l}(0.12 \\
0.18 \\
0.21)\end{array}$ & $\begin{array}{l}(0.31 \\
0.32 \\
0.32)\end{array}$ & $\begin{array}{l}(0.45 \\
0.43 \\
0.41)\end{array}$ & $\begin{array}{l}(0.28 \\
0.29 \\
0.30)\end{array}$ & $\begin{array}{l}(0.14 \\
0.20 \\
0.23)\end{array}$ & $\begin{array}{c}(0.23 \\
0.26 \\
0.28)\end{array}$ & $\begin{array}{l}(0.32, \\
0.33, \\
0.33)\end{array}$ & $\begin{array}{c}(0.12, \\
0.18, \\
0.21)\end{array}$ \\
\hline A3 & $\begin{array}{l}(0.44 \\
0.42 \\
0.41)\end{array}$ & $\begin{array}{c}(0.42 \\
0.41 \\
0.40)\end{array}$ & $\begin{array}{l}(0.12 \\
0.18 \\
0.21)\end{array}$ & $\begin{array}{l}(0.42 \\
0.40 \\
0.39)\end{array}$ & $\begin{array}{l}(0.30 \\
0.32 \\
0.33)\end{array}$ & $\begin{array}{l}(0.28 \\
0.29 \\
0.30)\end{array}$ & $\begin{array}{l}(0.42 \\
0.40 \\
0.39)\end{array}$ & $\begin{array}{l}(0.35 \\
0.35 \\
0.35)\end{array}$ & $\begin{array}{l}(0.43, \\
0.41 \\
0.40)\end{array}$ & $\begin{array}{c}(0.12, \\
0.18, \\
0.21)\end{array}$ \\
\hline A4 & $\begin{array}{l}(0.44 \\
0.42 \\
0.41)\end{array}$ & $\begin{array}{c}(0.42 \\
0.41 \\
0.40)\end{array}$ & $\begin{array}{l}(0.24 \\
0.27 \\
0.28)\end{array}$ & $\begin{array}{l}(0.31 \\
0.32 \\
0.32)\end{array}$ & $\begin{array}{c}(0.15 \\
0.10 \\
0.08)\end{array}$ & $\begin{array}{c}(0.42 \\
0.39 \\
0.38)\end{array}$ & $\begin{array}{l}(0.57 \\
0.51 \\
0.47)\end{array}$ & $\begin{array}{c}(0.47 \\
0.44 \\
0.42)\end{array}$ & $\begin{array}{l}(0.43, \\
0.41 \\
0.40)\end{array}$ & $\begin{array}{c}(0.48 \\
0.45 \\
0.42)\end{array}$ \\
\hline A5 & $\begin{array}{l}(0.11, \\
0.17 \\
0.20)\end{array}$ & $\begin{array}{c}(0.42, \\
0.41 \\
0.40)\end{array}$ & $\begin{array}{l}(0.36 \\
0.36 \\
0.35)\end{array}$ & $\begin{array}{l}(0.21 \\
0.24 \\
0.26)\end{array}$ & $\begin{array}{c}(0.45 \\
0.43 \\
0.41)\end{array}$ & $\begin{array}{l}(0.28 \\
0.29 \\
0.30)\end{array}$ & $\begin{array}{l}(0.28 \\
0.30 \\
0.31)\end{array}$ & $\begin{array}{c}(0.11 \\
0.17 \\
0.21)\end{array}$ & $\begin{array}{l}(0.21, \\
0.24 \\
0.26)\end{array}$ & $\begin{array}{c}(0.36, \\
0.36, \\
0.35)\end{array}$ \\
\hline A6 & $\begin{array}{l}(0.44 \\
0.42 \\
0.41)\end{array}$ & $\begin{array}{c}(0.14 \\
0.20 \\
0.24)\end{array}$ & $\begin{array}{l}(0.36, \\
0.36 \\
0.35)\end{array}$ & $\begin{array}{l}(0.10 \\
0.16 \\
0.19)\end{array}$ & $\begin{array}{l}(0.45 \\
0.43 \\
0.41)\end{array}$ & $\begin{array}{c}(0.28 \\
0.29 \\
0.30)\end{array}$ & $\begin{array}{c}(0.42 \\
0.40 \\
0.39)\end{array}$ & $\begin{array}{l}(0.35 \\
0.35 \\
0.35)\end{array}$ & $\begin{array}{l}(0.21, \\
0.24 \\
0.26)\end{array}$ & $\begin{array}{c}(0.36 \\
0.36 \\
0.35)\end{array}$ \\
\hline A7 & $\begin{array}{l}(0.11 \\
0.17 \\
0.20)\end{array}$ & $\begin{array}{c}(0.41 \\
0.10 \\
0.08)\end{array}$ & $\begin{array}{c}(0.36, \\
0.36, \\
0.35)\end{array}$ & $\begin{array}{c}(0.42 \\
0.40 \\
0.39)\end{array}$ & $\begin{array}{c}(0.15 \\
0.10 \\
0.08)\end{array}$ & $\begin{array}{c}(0.42 \\
0.39 \\
0.38)\end{array}$ & $\begin{array}{l}(0.28 \\
0.30 \\
0.31)\end{array}$ & $\begin{array}{l}(0.35 \\
0.35 \\
0.35)\end{array}$ & $\begin{array}{c}(0.43, \\
0.41 \\
0.40)\end{array}$ & $\begin{array}{c}(0.36 \\
0.36 \\
0.35)\end{array}$ \\
\hline A8 & $\begin{array}{l}(0.33 \\
0.34 \\
0.34)\end{array}$ & $\begin{array}{c}(0.14 \\
0.20 \\
0.24)\end{array}$ & $\begin{array}{l}(0.36 \\
0.36 \\
0.35)\end{array}$ & $\begin{array}{l}(0.31 \\
0.32 \\
0.32)\end{array}$ & $\begin{array}{l}(0.45 \\
0.43 \\
0.41)\end{array}$ & $\begin{array}{l}(0.28 \\
0.29 \\
0.30)\end{array}$ & $\begin{array}{c}(0.14 \\
0.20 \\
0.23)\end{array}$ & $\begin{array}{l}(0.23 \\
0.26 \\
0.28)\end{array}$ & $\begin{array}{l}(0.32, \\
0.33, \\
0.33)\end{array}$ & $\begin{array}{c}(0.36, \\
0.36, \\
0.35)\end{array}$ \\
\hline A9 & $\begin{array}{l}(0.44 \\
0.42 \\
0.41)\end{array}$ & $\begin{array}{c}(0.14 \\
0.20 \\
0.24)\end{array}$ & $\begin{array}{l}(0.48 \\
0.45 \\
0.42)\end{array}$ & $\begin{array}{l}(0.31 \\
0.32 \\
0.32)\end{array}$ & $\begin{array}{c}(0.15 \\
0.10 \\
0.08)\end{array}$ & $\begin{array}{l}(0.28 \\
0.29 \\
0.30)\end{array}$ & $\begin{array}{l}(0.28 \\
0.30 \\
0.31)\end{array}$ & $\begin{array}{l}(0.35 \\
0.35 \\
0.35)\end{array}$ & $\begin{array}{c}(0.32, \\
0.33, \\
0.33)\end{array}$ & $\begin{array}{c}(0.24 \\
0.27 \\
0.28)\end{array}$ \\
\hline
\end{tabular}

Consequently, the assessment values of each stage of the F-MULTIMOORA method were calculated based on the aforementioned procedures in Section 3.1. The assessment values and the final rankings of each stage as well as the dominance theory are shown in the Table 7. 
Table 7. Assessment values and rankings of the F-MULTIMOORA regarding job satisfaction factors.

\begin{tabular}{cccccccc}
\hline \multirow{2}{*}{ Influencing Factors } & \multicolumn{3}{c}{ Assessment Values } & \multicolumn{3}{c}{ Rankings } \\
\cline { 2 - 7 } & $\boldsymbol{B N P}_{\widetilde{\boldsymbol{y}}_{\boldsymbol{i}}^{*}}$ & $\boldsymbol{z}_{\boldsymbol{i}}^{*}$ & $\boldsymbol{B N P}_{\widetilde{\boldsymbol{U}}_{\boldsymbol{i}}^{* \prime}}$ & $\boldsymbol{F R S}$ & $\boldsymbol{F R \boldsymbol { P }}$ & $\boldsymbol{F} \boldsymbol{F} \boldsymbol{F}$ & Final Rank \\
\hline $\mathrm{A} 1$ & 2.18823 & 0.32349 & 0.00235 & 3 & 8 & 3 & 3 \\
$\mathrm{~A} 2$ & 1.47133 & 0.27160 & 0.00021 & 8 & 3 & 8 & 8 \\
$\mathrm{~A} 3$ & 2.39508 & 0.27160 & 0.00392 & 2 & 2 & 2 & 2 \\
A4 & 2.89269 & 0.30618 & 0.01636 & 1 & 4 & 1 & 1 \\
A5 & 1.42310 & 0.25630 & 0.00015 & 9 & 1 & 9 & 9 \\
A6 & 1.67263 & 0.30779 & 0.00035 & 6 & 6 & 6 & 6 \\
A7 & 1.93577 & 0.41039 & 0.00058 & 4 & 9 & 5 & 5 \\
A8 & 1.53960 & 0.30779 & 0.00028 & 7 & 7 & 7 & 7 \\
A9 & 1.85043 & 0.30779 & 0.00084 & 5 & 5 & 4 & 4 \\
\hline
\end{tabular}

As aforementioned, the PLS-SEM approach based on the CFA technique was utilized in the current study. Figure 3 illustrates the SEM model of the proposed case study based on nine influencing factors, which were identified considering expert comments, discusses the profiles of the corresponding employees, which are demonstrated in Table 8 and library research.

Table 8. Profile of the respondents related to the statistical procedure.

\begin{tabular}{ccc}
\hline Demographic Items & Frequency & Percentile \\
\hline Gender & 200 & 100 \\
Male & 0 & 0 \\
Female & & \\
Mariel Status & 112 & 56 \\
Single & 88 & 44 \\
Married & & \\
Age & 14 & 7 \\
Less than 20 & 67 & 33.5 \\
20-30 & 87 & 43.5 \\
$31-40$ & 22 & 11 \\
$41-50$ & 10 & 5 \\
50 \& Above & & \\
Job Level & 61 & 30.5 \\
Employee & 71 & 35.5 \\
Expert & 26 & 13 \\
Supervisor & 26 & 13 \\
Manager & 10 & 5 \\
Top Manager & 6 & 3 \\
CEO &
\end{tabular}




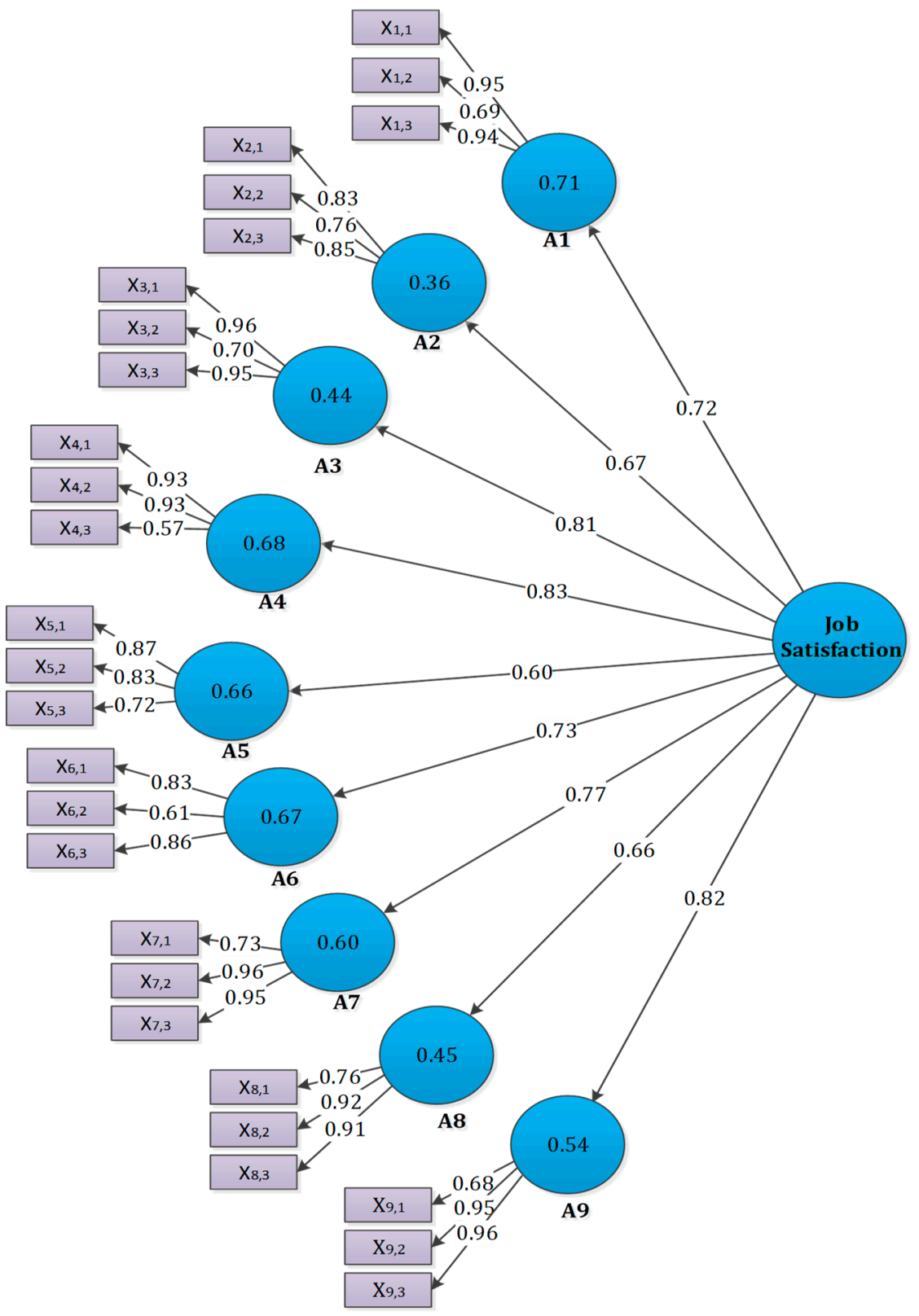

Figure 3. The influential factors in job satisfaction based on a PLS-SEM model.

Moreover, Table 9 demonstrates the reliability analysis, overview of the statistical factors and indices of the proposed model based on the PLS-SEM approach in the suggested case study.

Table 9. Construct measures and statistics for nine influencing factors in the job satisfaction.

\begin{tabular}{|c|c|c|c|c|c|c|c|c|c|}
\hline Research Construct & & $\begin{array}{l}\text { Sample } \\
\text { Mean }\end{array}$ & $\begin{array}{l}\text { Standard } \\
\text { Deviation }\end{array}$ & $\begin{array}{l}\text { Standard } \\
\text { Error }\end{array}$ & $\begin{array}{c}\mathrm{T} \\
\text { Statistics }\end{array}$ & $\begin{array}{l}\text { Cronbach's } \\
\text { Alpha }\end{array}$ & $\begin{array}{c}\text { C.R } \\
\text { Value }\end{array}$ & $\begin{array}{l}\text { AVE } \\
\text { Value }\end{array}$ & $\begin{array}{l}\text { Factor } \\
\text { Loading }\end{array}$ \\
\hline $\mathrm{A} 1(\mathrm{~F} 1)$ & $\begin{array}{l}X_{1,1} \\
X_{1,2} \\
X_{1,3}\end{array}$ & 0.71 & 0.05 & 0.05 & 13.85 & 0.84 & 0.91 & 0.77 & $\begin{array}{l}0.95 \\
0.69 \\
0.94\end{array}$ \\
\hline A2(F2) & $\begin{array}{l}X_{2,1} \\
X_{2,2} \\
X_{2,3}\end{array}$ & 0.66 & 0.07 & 0.07 & 8.41 & 0.75 & 0.86 & 0.67 & $\begin{array}{l}0.83 \\
0.76 \\
0.85\end{array}$ \\
\hline
\end{tabular}


Table 9. Cont

\begin{tabular}{|c|c|c|c|c|c|c|c|c|c|c|}
\hline \multicolumn{3}{|c|}{ Research Construct } & $\begin{array}{l}\text { Sample } \\
\text { Mean }\end{array}$ & $\begin{array}{l}\text { Standard } \\
\text { Deviation }\end{array}$ & $\begin{array}{l}\text { Standard } \\
\text { Error }\end{array}$ & $\begin{array}{c}T \\
\text { Statistics }\end{array}$ & $\begin{array}{l}\text { Cronbach's } \\
\text { Alpha }\end{array}$ & $\begin{array}{l}\text { C.R } \\
\text { Value }\end{array}$ & $\begin{array}{l}\text { AVE } \\
\text { Value }\end{array}$ & $\begin{array}{l}\text { Factor } \\
\text { Loading }\end{array}$ \\
\hline \multirow{5}{*}{ Job Satisfaction } & A3(F3) & $\begin{array}{l}X_{3,1} \\
X_{3,2} \\
X_{3,3}\end{array}$ & 0.8 & 0.07 & 0.07 & 9.52 & 0.85 & 0.91 & 0.78 & $\begin{array}{c}0.96 \\
0.7 \\
0.95\end{array}$ \\
\hline & $\mathrm{A} 4(\mathrm{~F} 4)$ & $\begin{array}{l}X_{4,1} \\
X_{4,2} \\
X_{4,3}\end{array}$ & 0.82 & 0.03 & 0.03 & 23.66 & 0.74 & 0.86 & 0.69 & $\begin{array}{l}0.93 \\
0.93 \\
0.57\end{array}$ \\
\hline & A6(F6) & $\begin{array}{l}X_{6,1} \\
X_{6,2} \\
X_{6,3}\end{array}$ & 0.72 & 0.03 & 0.03 & 26.63 & 0.71 & 0.84 & 0.63 & $\begin{array}{l}0.83 \\
0.61 \\
0.86\end{array}$ \\
\hline & A8(F8) & $\begin{array}{l}X_{8,1} \\
X_{8,2} \\
X_{8,3}\end{array}$ & 0.65 & 0.08 & 0.08 & 8.23 & 0.84 & 0.90 & 0.76 & $\begin{array}{l}0.76 \\
0.92 \\
0.91\end{array}$ \\
\hline & A9(F9) & $\begin{array}{l}X_{9,1} \\
X_{9,2} \\
X_{9,3}\end{array}$ & 0.81 & 0.05 & 0.05 & 15.86 & 0.83 & 0.90 & 0.76 & $\begin{array}{l}0.68 \\
0.95 \\
0.96\end{array}$ \\
\hline
\end{tabular}

Table 9 demonstrates the related factor loading values of the questions are higher than 0.40 . On the other hand, the factor loading values are fluctuating between 0.57 and 0.96 . Additionally, the results of the $\mathrm{T}$ test in every factor loading variable are meaningful and accurate lower than 0.01 . Furthermore, based on Cronbach's [62], the acceptable value of alpha for model reliability is 0.70, in which in the current study the alpha value for every variable is more than 0.70 . Consequently, the composite reliability $(\mathrm{CR})$ values for variables are obtained as more than 0.70 in each variable. The average variance-extracted (AVE) values describe that the convergent validity of the variables is convenient. Ultimately, to calculate the discriminant validity, the cross loading $(\mathrm{CL})$ test, along with Fornell-Larcker [63] test, has been applied. Table 10 demonstrates the CL factors of the current study, in which Qi is the indicator of the questions from the questionnaire used to gather the input data in the present study.

Table 10. Demonstration of the convergent validity of factors (the blue numbers are cross loading factors).

\begin{tabular}{cccccccccc}
\hline & A1 & A2 & A3 & A4 & A5 & A6 & A7 & A8 & A9 \\
\hline Q4 & 0.95 & 0.28 & 0.30 & 0.49 & 0.46 & 0.47 & 0.42 & 0.47 & 0.52 \\
Q5 & 0.69 & 0.34 & 0.17 & 0.39 & 0.45 & 0.42 & 0.38 & 0.45 & 0.38 \\
Q6 & 0.95 & 0.28 & 0.30 & 0.49 & 0.46 & 0.47 & 0.42 & 0.47 & 0.52 \\
Q10 & 0.31 & 0.84 & 0.39 & 0.50 & 0.27 & 0.22 & 0.45 & 0.29 & 0.22 \\
Q11 & 0.20 & 0.76 & 0.39 & 0.38 & 0.21 & 0.23 & 0.61 & 0.22 & 0.17 \\
Q12 & 0.31 & 0.85 & 0.27 & 0.44 & 0.30 & 0.25 & 0.45 & 0.32 & 0.23 \\
Q13 & 0.30 & 0.32 & 0.96 & 0.57 & 0.35 & 0.44 & 0.45 & 0.22 & 0.34 \\
Q15 & 0.19 & 0.51 & 0.70 & 0.47 & 0.22 & 0.25 & 0.44 & 0.18 & 0.36 \\
Q16 & 0.30 & 0.32 & 0.96 & 0.57 & 0.35 & 0.44 & 0.45 & 0.22 & 0.34 \\
Q20 & 0.49 & 0.49 & 0.30 & 0.93 & 0.53 & 0.45 & 0.54 & 0.42 & 0.51 \\
Q23 & 0.49 & 0.49 & 0.30 & 0.93 & 0.53 & 0.45 & 0.54 & 0.42 & 0.51 \\
Q24 & 0.30 & 0.32 & 0.96 & 0.57 & 0.35 & 0.44 & 0.45 & 0.22 & 0.34 \\
Q25 & 0.49 & 0.22 & 0.28 & 0.45 & 0.87 & 0.86 & 0.41 & 0.58 & 0.50 \\
Q27 & 0.43 & 0.24 & 0.36 & 0.50 & 0.83 & 0.83 & 0.47 & 0.46 & 0.55 \\
Q28 & 0.34 & 0.33 & 0.20 & 0.45 & 0.72 & 0.49 & 0.29 & 0.34 & 0.55 \\
Q31 & 0.43 & 0.24 & 0.36 & 0.50 & 0.83 & 0.83 & 0.47 & 0.46 & 0.55 \\
Q35 & 0.32 & 0.23 & 0.44 & 0.35 & 0.45 & 0.68 & 0.31 & 0.33 & 0.39 \\
\hline
\end{tabular}


Table 10. Cont.

\begin{tabular}{cccccccccc}
\hline & A1 & A2 & A3 & A4 & A5 & A6 & A7 & A8 & A9 \\
\hline Q36 & 0.49 & 0.22 & 0.28 & 0.45 & 0.87 & 0.86 & 0.41 & 0.58 & 0.50 \\
Q37 & 0.37 & 0.51 & 0.51 & 0.46 & 0.38 & 0.44 & 0.73 & 0.30 & 0.34 \\
Q39 & 0.43 & 0.56 & 0.42 & 0.59 & 0.46 & 0.45 & 0.96 & 0.46 & 0.43 \\
Q42 & 0.43 & 0.56 & 0.42 & 0.59 & 0.46 & 0.45 & 0.96 & 0.46 & 0.43 \\
Q43 & 0.40 & 0.23 & 0.35 & 0.41 & 0.62 & 0.61 & 0.48 & 0.76 & 0.45 \\
Q44 & 0.48 & 0.32 & 0.11 & 0.35 & 0.42 & 0.44 & 0.35 & 0.92 & 0.23 \\
Q48 & 0.48 & 0.32 & 0.11 & 0.35 & 0.42 & 0.44 & 0.35 & 0.92 & 0.23 \\
Q51 & 0.53 & 0.21 & 0.21 & 0.37 & 0.46 & 0.43 & 0.42 & 0.37 & 0.68 \\
Q53 & 0.46 & 0.23 & 0.40 & 0.53 & 0.61 & 0.57 & 0.38 & 0.30 & 0.95 \\
Q54 & 0.46 & 0.23 & 0.40 & 0.53 & 0.61 & 0.57 & 0.38 & 0.30 & 0.95 \\
\hline
\end{tabular}

The crosswise factors and discriminant validity have been presented in Table 11, which demonstrates that the suggested SEM model achieved an acceptable validity. Table 12 describes the path coefficients which were calculated from the path analysis, in which the final rankings were calculated and ranked from the path coefficients.

Table 11. The discriminant validity of the factors.

\begin{tabular}{lccccccccc}
\hline & A1 & A2 & A3 & A4 & A5 & A6 & A7 & A8 & A9 \\
\hline A1 & 0.88 & & & & & & & & \\
A2 & 0.34 & 0.82 & & & & & & & \\
A3 & 0.30 & 0.43 & 0.88 & & & & & & \\
A4 & 0.53 & 0.54 & 0.61 & 0.83 & & & & & \\
A5 & 0.52 & 0.32 & 0.35 & 0.57 & 0.81 & & & & \\
A6 & 0.52 & 0.29 & 0.44 & 0.55 & 0.71 & 0.79 & & & \\
A7 & 0.47 & 0.62 & 0.50 & 0.62 & 0.49 & 0.50 & 0.89 & & \\
A8 & 0.53 & 0.34 & 0.24 & 0.44 & 0.58 & 0.58 & 0.46 & 0.87 & \\
A9 & 0.55 & 0.25 & 0.39 & 0.56 & 0.65 & 0.61 & 0.45 & 0.37 & 0.87 \\
\hline
\end{tabular}

Table 12. The final results of the SEM approach regarding influencing factors in job satisfaction.

\begin{tabular}{cccccc}
\hline Influencing Factors & Path coefficients & T Statistics & R Square & Rejected/Supported & Final Rank \\
\hline A1 & 0.72 & 13.85 & 0.71 & Supported & 6 \\
A2 & 0.67 & 9.52 & 0.44 & Supported & 8 \\
A3 & 0.81 & 22.83 & 0.66 & Supported & 3 \\
A4 & 0.83 & 23.66 & 0.68 & Supported & 1 \\
A5 & 0.60 & 8.41 & 0.36 & Supported & 9 \\
A6 & 0.73 & 15.86 & 0.54 & Supported & 5 \\
A7 & 0.77 & 15.69 & 0.60 & Supported & 4 \\
A8 & 0.66 & 8.23 & 0.45 & Supported & 7 \\
A9 & 0.82 & 26.63 & 0.67 & Supported & 2 \\
\hline
\end{tabular}

Furthermore, based on the factor loadings that have been calculated to evaluate the influencing factors in job satisfaction, the wage and salary properties obtained the highest rank, which means it is the most important element to assess the job satisfaction in the case study. Consequently, as aforementioned, to test the proposed statistical algorithm, a goodness-of-fit (GOF) index is suggested by Tenenhaus et al. [64], considering PLS logic which has been demonstrated in Equation (23).

Moreover, the GOF index value was calculated to be 0.612 , which means the GOF value obtained a high and acceptable in the current study, i.e., the present model consists of great fit index. Moreover, in order to validate the proposed framework in the current study and to compare the results of applied methods in the scenario of the real-world case study, a comparison of mentioned propositions is presented in Table 13. 
Table 13. Comparison between rankings of the FMCDM approach, PLS-SEM method, and expert judgments.

\begin{tabular}{cccc}
\hline \multirow{2}{*}{ Influencing Factors } & \multicolumn{3}{c}{ Final Ranks } \\
\cline { 2 - 4 } & $\begin{array}{c}\text { FMCDM: } \\
\text { Fuzzy-MULTIMOORA }\end{array}$ & $\begin{array}{c}\text { Statistical Approach: } \\
\text { PLS-SEM }\end{array}$ & Expert Judgements \\
\hline A1 & 3 & 6 & 3 \\
A2 & 8 & 8 & 9 \\
A3 & 2 & 3 & 8 \\
A4 & 1 & 1 & 1 \\
A5 & 9 & 9 & 5 \\
A6 & 6 & 5 & 2 \\
A7 & 5 & 4 & 6 \\
A8 & 7 & 7 & 7 \\
A9 & 4 & 2 & 4 \\
\hline
\end{tabular}

The Spearman's rank correlation coefficient simplifies the evaluation process of the similarity of the rankings. A coefficient is a real number ranging between -1 and 1. The Spearman's coefficient equal to 1 denotes identical rankings and -1 indicates opposite rankings. Figure 4 illustrates the correlation between ranking lists by utilizing the Spearman's rank correlation coefficient, which is based on the rankings presented in Table 13. The correlation coefficient of the Spearman's rank based on similarity of rankings was calculated as follows:

$$
r_{s}=1-\frac{\sum_{i=1}^{n} D^{2}}{n\left(n^{2}-1\right)}
$$

where $D$ is differences between the two ranks and $n$ denotes the sample size.

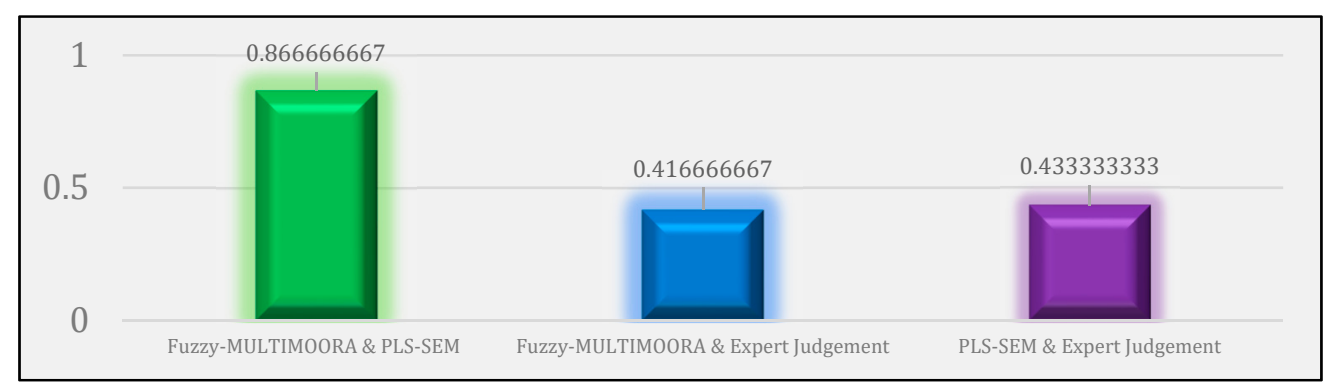

Figure 4. Correlation between the rankings based on the Spearman's correlation coefficient.

Figure 4 shows that the correlation between the FMCDM approach and the statistical technique proposed in the current study is 0.86 , which is a high correlation compared to other ranks. Furthermore, the high correlation of the proposed method in this study shows the suggested framework, in order to validate the FMCDM method and the statistical approach at the same time, i.e., the proposed hybrid validation is accurate. It is also worth mentioning that a decent solution to such practical case can include preferences of every employee of the organization in the job satisfaction evaluation. In this case, while the items and factors of job satisfaction might be the same, the input data will change based on the mentioned structure. In such cases, group decision-making approaches combined with fuzzy ontologies and multi-granular linguistic modelling methods can become useful $[65,66]$. It is recommended to apply such methodologies and compare it to this study, in order to see if there is any correlation between high-level mangers comments and employees preferences in regard to factors influencing job satisfaction. Additionally, along with the abovementioned methodology, it is also suggested to use novel data-gathering approaches such as user experience questionnaires (UEQ-S) [67]. 


\subsection{Discusssions and Managerial Implications}

With a view to presenting a comprehensive analysis of the final result of the current study, which has been obtained based on the proposed algorithm using a combination of F-MULTIMOORA and a statistical approach in the suggested real-world case study, Table 14 demonstrates a detailed opportunity for improvement (OFI) plan based on the obtained evaluation of each influencing factor in the job satisfaction in the mentioned organization. Consequently, the proposed detailed analysis of each factor could play a vital role in improving the evaluation of influencing factors in job satisfaction, and improving the satisfaction of employees considering adjusting factors, and in planning a corrective action. To sum up, the final analyses of the case study, a sensitivity analysis based on the proposed methods, i.e., FMCDM, and the statistical approach are provided in Figures 5 and 6.

Table 14. Comprehensive analysis of the opportunity for improvement.

\begin{tabular}{|c|c|c|}
\hline \multirow{2}{*}{$\begin{array}{l}\text { Influencing Factor in } \\
\text { Job Satisfaction }\end{array}$} & \multicolumn{2}{|c|}{ Comprehensive Data Analysis } \\
\hline & Root Cause Description & Opportunity for Improvement \\
\hline Organization Commitment (A1) & $\begin{array}{l}\text { Convergence and lobbying to recruit personnel, lack } \\
\text { of clear goals in the organization, lack of performance } \\
\text { appraisal system for mid-level managers, deficiency } \\
\text { in reward and punishment system. }\end{array}$ & $\begin{array}{l}\text { Employing talented and motivated personnel, job } \\
\text { compliance establishment in the organization, } \\
\text { creating a supportive atmosphere in the organization, } \\
\text { and enhancing long-term payment systems. }\end{array}$ \\
\hline Leadership (A2) & $\begin{array}{l}\text { The main reason for the relative satisfaction of this } \\
\text { factor in the organization is the performance } \\
\text { evaluation centers evaluating the performance of the } \\
\text { high-level managers and leaders of the organization. } \\
\text { However, still, there is lack of satisfaction in the } \\
\text { leadership in the project-based structure. }\end{array}$ & $\begin{array}{l}\text { To keep the satisfaction levels in the current situation } \\
\text { or enhance the satisfaction in employees considering } \\
\text { leadership factors, the long term performance } \\
\text { appraisal mechanisms should be planned } \\
\text { and continued. }\end{array}$ \\
\hline Job Security (A3) & $\begin{array}{l}\text { In general, the high-level supervisors and managers } \\
\text { usually have a high level of job security due to their } \\
\text { key competencies. In lower level positions due to the } \\
\text { lack of transparency in the organization, the job } \\
\text { security is low. }\end{array}$ & $\begin{array}{l}\text { Designing preventive mechanisms is one of the } \\
\text { furthermost effective approaches towards preventing } \\
\text { the fear of job loss in any organization level. } \\
\text { Preventive mechanisms include: long-term contracts, } \\
\text { long-term loans, converting the status of day-to-day } \\
\text { employees to the contractor and contractors to } \\
\text { the official. }\end{array}$ \\
\hline Wage and Salary (A4) & $\begin{array}{l}\text { Transparency in contracts is very unclear among } \\
\text { high-level managers in the current organization. } \\
\text { Also, payment quality and legal issues for mid-level } \\
\text { managers and supervisors are very controversial. } \\
\text { Furthermore, justice in calculating salaries is vague } \\
\text { for the technicians and labors. Consequently, the } \\
\text { obscurity of upstream rules in the organization } \\
\text { results in low level of satisfaction of this factor. }\end{array}$ & $\begin{array}{l}\text { This factor can be examined and improved from } \\
\text { three different points of views: (a) justice-lack of } \\
\text { discrimination to determine rights and to observe all } \\
\text { laws; (b) transparency - with a view to developing } \\
\text { transparency among all levels of organization, it is } \\
\text { suggested to increase the knowledge level of } \\
\text { employees considering their legal rights; (c) } \\
\text { quality—ensuring the correct way of } \\
\text { calculating rights. }\end{array}$ \\
\hline Job Stress (A5) & $\begin{array}{l}\text { The working pressures in this organization in most of } \\
\text { the sectors are under control, except the } \\
\text { project-based sector in which the job stress due to the } \\
\text { working conditions is very high among project } \\
\text { managers and experts. }\end{array}$ & $\begin{array}{l}\text { In order to decrease the level of stress for every } \\
\text { occupational level, it is suggested to plan a } \\
\text { physio-mental analysis for every employee (which is } \\
\text { not available in the current case study) to control the } \\
\text { mental health of personnel. }\end{array}$ \\
\hline $\begin{array}{l}\text { Individual Development } \\
\text { Possibility (A6) }\end{array}$ & $\begin{array}{l}\text { Regarding management in the current case study, it } \\
\text { appears that specialized training, personal growth } \\
\text { and individual development do not matter, and } \\
\text { individual development mechanisms are defective. }\end{array}$ & $\begin{array}{l}\text { Designing competency systems and implying the } \\
\text { proposed system in the organizations is an effective } \\
\text { approach to increasing the personal growth and } \\
\text { individual development for employees. }\end{array}$ \\
\hline Amenities (A7) & $\begin{array}{l}\text { In the current organization, welfare services have a } \\
\text { low position in the employee's point of view. } \\
\text { Furthermore, the management of these kinds of } \\
\text { services is not important to be provided for the } \\
\text { personnel. }\end{array}$ & $\begin{array}{l}\text { Needs assessment of occupational levels and job } \\
\text { positions is an accurate way of understanding the } \\
\text { specified need of employees and offering the most } \\
\text { required amenities to enhance satisfaction. }\end{array}$ \\
\hline Personal Relationship (A8) & $\begin{array}{l}\text { The workplace environment in the current } \\
\text { organization is a single-sex environment, in which } \\
\text { only male employees are working. Consequently, } \\
\text { expectations of employees for having a productive } \\
\text { and happy workplace decrease. Furthermore, the } \\
\text { quality of life in such environments is deficient, due } \\
\text { to the specific structure of the workplace. }\end{array}$ & $\begin{array}{l}\text { To enhance the quality of the workplace } \\
\text { environment, the culture and the core environment } \\
\text { have to change. Therefore, it is suggested to plan a } \\
\text { close-up time for employees in order to make more } \\
\text { communications. Furthermore, designing a } \\
\text { committee of practice to plan an effective } \\
\text { communication for employees is also worthy. }\end{array}$ \\
\hline $\begin{array}{l}\text { Education and Learning } \\
\text { Opportunity (A9) }\end{array}$ & $\begin{array}{l}\text { Disagreement over ideas and comments among } \\
\text { experts and management level is evident concerning } \\
\text { this factor. Because a big part of the organization is } \\
\text { project-based, the long-term planning for education } \\
\text { and learning is considered as a waste in this } \\
\text { organization, and in their point of view, training at } \\
\text { the service seems enough. }\end{array}$ & $\begin{array}{l}\text { It is suggested that with a long-term plan based on } \\
\text { the job analysis of every job position, the specific } \\
\text { needs of each job position are obtained in order to } \\
\text { imply the empowerment through education and } \\
\text { learning opportunities. }\end{array}$ \\
\hline
\end{tabular}




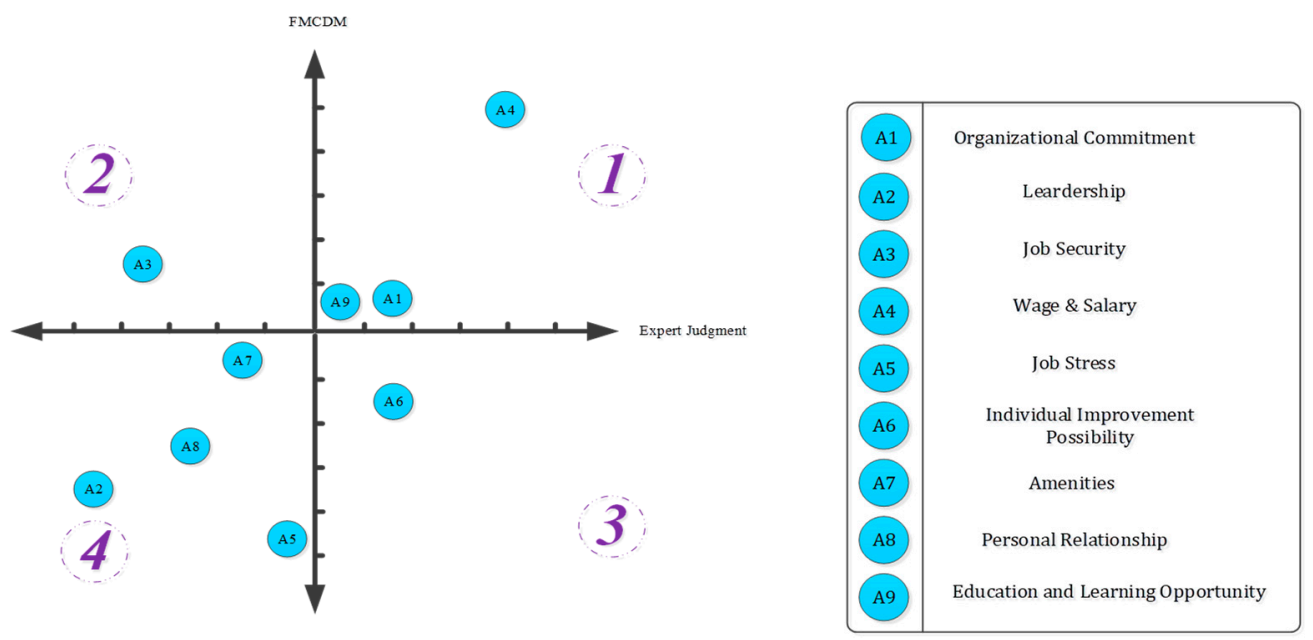

Figure 5. Sensitivity analysis of FMCDM approach and expert judgments.
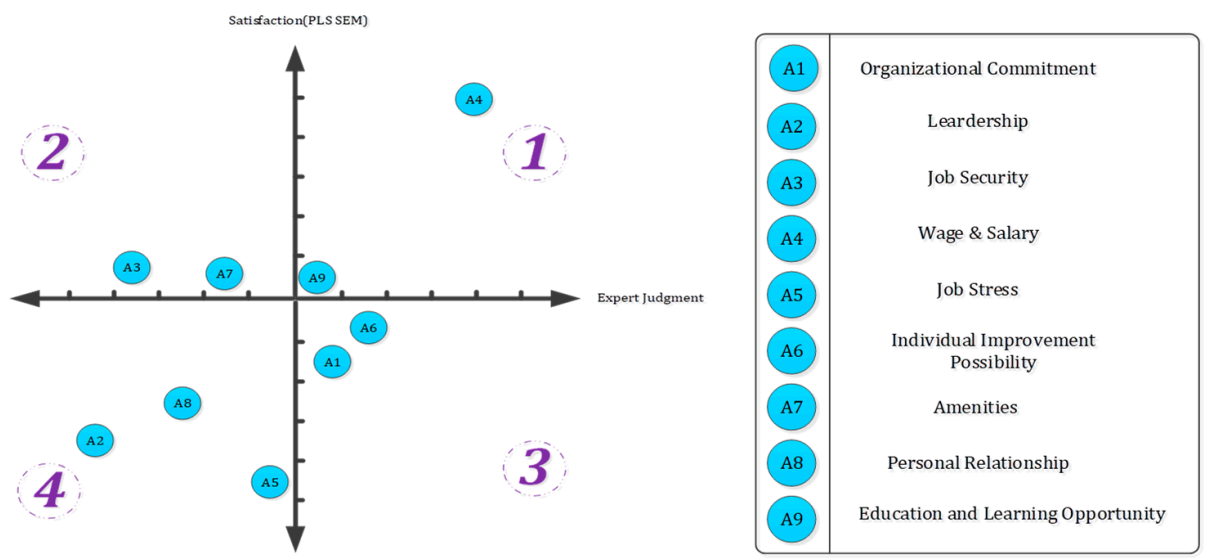

Figure 6. Sensitivity analysis of the statistical approach and expert judgments.

Based on Figures 5 and 6, four areas are identified and available in this analysis, in which area (1) demonstrates a high level of importance measures and a high level of impacts on satisfactions. The factors that are located in this area are dominant and supreme factors because any improvement in the factors in this area results in a huge amount of satisfaction from employees in the organization.

Area (2) shows that the factors located in this area have a high level of impacts on satisfactions, but based on expert comments, these factors have a lack of importance. Therefore, improvement of factors located in this area may result in ineffectual circumstances or may be harmful to the organizations.

Area (3) illustrates a high level of importance along with a low level of impacts on satisfactions for employees. The factors locating in this area are the main reason why employees abandoned the organization, especially the experts. Therefore, area (3) is a critical zone, and to improve the satisfaction, employees' need for long-term planning is fundamental.

Ultimately, in area (4), the level of importance and level of impacts on satisfactions are shallow. Consequently, improving the factors that are located in this area imposes unnecessary costs to the organization, which results in idle circumstances to make progress in the organization.

\section{Conclusions}

In any competitive organization, it is a crucial factor in maintaining primary improvement tools of competitiveness such as the human factor. To achieve a better understanding of the work-force in any organization, evaluation of the job satisfaction is provided. Therefore, evaluating the influential factors in the job satisfaction is significantly important. The current study presented a novel hybrid 
validation framework based on the F-MULTIMOORA method and PLS-SEM approach considering CFA, to analyse the influential factors in job satisfaction in a real-world case study. The criteria and the influential factors in job satisfaction as candidate alternatives in the current study were identified, and a comprehensive description of each criterion and alternative was provided. Based on the F-MULTIMOORA approach, an assessment of the influencing factors has been provided. Additionally, a CFA based on the PLS-SEM approach has been provided to evaluate the measurement of the influencing factors in job satisfaction. The correlations between the rankings of the statistical approach, FMCDM method and expert judgments have been examined applying the Spearman's rank correlation coefficients. Finally, a comprehensive analysis of the real-world case study has been provided based on the proposed framework and the expert judgments from the case study, in which a detailed opportunity for improvement plan has been presented based on the systematic analysis of the current scenario in the case study, in order to utilize the procedure with corrective action.

Future suggestions and developments of the current study may be as follows. First, the input data of the MCDM approach, which have been suggested in the current study, can be extended to the cases, in which the data of the problem have different mathematical forms such as extensions of fuzzy sets, interval data structure, and granular data structures. Second, the validation framework in this study utilized the F-MULTIMOORA approach, in which the MCDM framework could be replaced by other MCDM techniques such as Axiomatic Design (AD), the Technique for Order of Preference by Similarity to Ideal Solution (TOPSIS), and Decision-Making Trial and Evaluation Laboratory (DEMATEL). Third, the statistical process in the proposed study is based on the PLS-SEM approach; for the future studies, the covariance-based methods (CB-SEM) can also be applied. Fourth, significance coefficients of attributes could be combined with the assessment phase to achieve more expert-based decisions, which may be attained subjectively or objectively. Subjective significance coefficients may be computed by applying various methods like the ANP, AHP, and BWM. It is recommended to use hierarchical weighting methods such as the hierarchical group BWM suggested by Maghsoodi et al. [68], in order to reach the optimal weights based on a group decision-making approach. Fifth, the validation framework could also be implemented in many other applications with the input content of statistical values, such as the effect of influential factors on performance appraisal.

Author Contributions: Conceptualization, A.I.M. and I.A.; methodology, A.I.M and M.A.; validation, A.I.M., I.A., Z.B. and M.A.; investigation, A.I.M and M.A.; resources, I.A. and Z.B.; data curation, I.A.; writing of the original draft preparation, A.I.M.; writing of review and editing, E.K.Z. and J.A.; supervision, E.K.Z. and J.A.; project administration, A.I.M. and E.K.Z.; funding acquisition, A.I.M., E.K.Z. and J.A.

Funding: This research received no external funding.

Conflicts of Interest: The authors declare no conflicts of interest.

\section{References}

1. Locke, E.A. The nature and causes of job satisfaction. In Handbook of Industrial and Organizational Psychology; American Psychological Association: Washington, DC, USA, 1976; pp. 1297-1349.

2. Spector, P.E. Job Satisfaction: Application, Assessment, Cause, and Consequences; SAGE Publications, Inc.: Thousand Oaks, CA, USA, 1997.

3. Özpehlivan, M.; Acar, A.Z. Development and validation of a multidimensional job satisfaction scale in different cultures. Cogent Soc. Sci. 2016, 30, 1-20. [CrossRef]

4. Baležentis, A.; Baležentis, T.; Brauers, W.K.M. Personnel selection based on computing with words and fuzzy Multimoora. Expert Syst. Appl. 2012, 39, 7961-7967. [CrossRef]

5. Shaout, A.; Yousif, M.K. Performance Evaluation-Methods and Techniques Survey. Int. J. Comput. Inf. Technol. 2014, 3, 966-979.

6. Keshavarz-Ghorabaee, M.; Amiri, M.; Zavadskas, E.K.; Turskis, Z.; Antucheviciene, J. An extended step-wiseweight assessment ratio analysis with symmetric interval type-2 fuzzy sets for determining the subjective weights of criteria in multi-criteria decision-making problems. Symmetry (Basel) 2018, 10, 91. [CrossRef] 
7. Tumen, S.; Zeydanli, T. Social Interactions in Job Satisfaction. Int. J. Manpow. 2016, 37, 426-455. [CrossRef]

8. Metle, M.K. Education, job satisfaction and gender in Kuwait. Int. J. Hum. Resour. Manag. 2001, 12, 311-332. [CrossRef]

9. Asrar-ul-Haq, M.; Kuchinke, K.P.; Iqbal, A. The relationship between corporate social responsibility, job satisfaction, and organizational commitment: Case of Pakistani higher education. J. Clean. Prod. 2017, 142, 2352-2363. [CrossRef]

10. Lee, Y.; Sabharwal, M. Education-Job Match, Salary, and Job Satisfaction Across the Public, Non-Profit, and For-Profit Sectors: Survey of recent college graduates. Public Manag. Rev. 2016, 18, 40-64. [CrossRef]

11. Hann, M.; Reeves, D.; Sibbald, B. Relationships between job satisfaction, intentions to leave family practice and actually leaving among family physicians in England. Eur. J. Public Health 2011, 21, 499-503. [CrossRef]

12. Mansor, N.; Mohd Noor, J.M.; Nik Hassan, N.F. Job satisfaction among the bankers: An investigation on Islamic financial institution in eastern region of Malaysia. Asian Soc. Sci. 2012, 8, 186-197. [CrossRef]

13. Elshout, R.; Scherp, E.; van der Feltz-Cornelis, C.M. Understanding the link between leadership style, employee satisfaction, and absenteeism: A mixed methods design study in a mental health care institution. Neuropsychiatr. Dis. Treat. 2013, 9, 823-837. [PubMed]

14. Ruchman, R.B.; Kwak, A.J.; Jaeger, J.; Sayegh, A. Job satisfaction of program directors in radiology: A survey of current program directors. Am. J. Roentgenol. 2013, 200, 238-247. [CrossRef] [PubMed]

15. Frey, R.-V.; Bayon, T.; Totzek, D. How Customer Satisfaction Affects Employee Satisfaction and Retention in a Professional Services Context. J. Serv. Res. 2013, 16, 503-517. [CrossRef]

16. Naqbi, S.A.A.; Hamidi, S.A.; Younis, M.Z.; Rivers, P.A. Determinants of Employee Satisfaction with Services of Human Resource Departments in the Fujairah Medical District (FMD) of the United Arab Emirates. J. Health Manag. 2014, 16, 271-287. [CrossRef]

17. Tansel, A.; Gazîoğlu, Ş. Management-employee relations, firm size and job satisfaction. Int. J. Manpow. 2014, 35, 1260-1275. [CrossRef]

18. Matthies-Baraibar, C.; Arcelay-Salazar, A.; Cantero-González, D.; Colina-Alonso, A.; García-Urbaneja, M.; González-Llinares, R.M.; Letona-Aranburu, J.; Martínez-Carazo, C.; Mateos-Del Pino, M.; Nuño-Solinís, R.; et al. Is organizational progress in the EFQM model related to employee satisfaction? BMC Health Serv. Res. 2014, 14, 468. [CrossRef] [PubMed]

19. Tso, G.K.F.; Liu, F.; Li, J. Identifying Factors of Employee Satisfaction: A Case Study of Chinese Resource-Based State-Owned Enterprises. Soc. Indic. Res. 2015, 123, 567-583. [CrossRef]

20. Leder, S.; Newsham, G.R.; Veitch, J.A.; Mancini, S.; Charles, K.E. Effects of office environment on employee satisfaction: A new analysis. Build. Res. Inf. 2016, 44, 34-50. [CrossRef]

21. Mathieu, C.; Fabi, B.; Lacoursière, R.; Raymond, L. The role of supervisory behavior, job satisfaction and organizational commitment on employee turnover. J. Manag. Organ. 2016, 22, 113-129. [CrossRef]

22. Jacobs, M.A.; Yu, W.; Chavez, R. The effect of internal communication and employee satisfaction on supply chain integration. Int. J. Prod. Econ. 2016, 171, 60-70. [CrossRef]

23. Barakat, S.R.; Isabella, G.; Boaventura, J.M.G.; Mazzon, J.A. The influence of corporate social responsibility on employee satisfaction. Manag. Decis. 2016, 54, 2325-2339. [CrossRef]

24. Boddy, C.R.; Taplin, R. The influence of corporate psychopaths on job satisfaction and its determinants. Int. J. Manpow. 2016, 37, 965-988. [CrossRef]

25. Koklic, M.K.; Kukar-Kinney, M.; Vegelj, S. An investigation of customer satisfaction with low-cost and full-service airline companies. J. Bus. Res. 2017, 80, 188-196. [CrossRef]

26. Tarcan, G.Y.; Tarcan, M.; Top, M. An analysis of relationship between burnout and job satisfaction among emergency health professionals. Total Qual. Manag. Bus. Excell. 2017, 28, 1339-1356. [CrossRef]

27. Holmberg, C.; Caro, J.; Sobis, I. Job satisfaction among Swedish mental health nursing personnel: Revisiting the two-factor theory. Int. J. Ment. Health Nurs. 2018, 27, 581-592. [CrossRef] [PubMed]

28. Bin Bae, K.; Yang, G. The Effects of Family-Friendly Policies on Job Satisfaction and Organizational Commitment. Public Pers. Manag. 2017, 46, 25-40.

29. Hafez, E.; AbouelNeel, R.; Elsaid, E. An Exploratory Study on How Talent Management Affects Employee Retention and Job Satisfaction for Personnel Administration in Ain Shams University Egypt. J. Manag. Strateg. 2017, 8, 1-17. [CrossRef] 
30. Hayes, B.; Bonner, A.; Pryor, J. Factors contributing to nurse job satisfaction in the acute hospital setting: A review of recent literature. J. Nurs. Manag. 2010, 18, 804-814. [CrossRef]

31. Zhu, Y. A review of job satisfaction. Asian Soc. Sci. 2013, 9, 293-298. [CrossRef]

32. Hantula, D.A. Job Satisfaction: The Management Tool and Leadership Responsibility. J. Organ. Behav. Manag. 2015, 35, 81-94. [CrossRef]

33. Brauers, W.K.M.; Zavadskas, E.K. The MOORA method and its application to privatization in a transition economy by A new method: The MOORA method. Control Cybern. 2006, 35, 445-469.

34. Brauers, W.K.M.; Zavadskas, E.K. Project management by multimoora as an instrument for transition economies. Technol. Econ. Dev. Econ. 2010, 16, 5-24. [CrossRef]

35. Baležentis, T.; Baležentis, A. A Survey on Development and Applications of the Multi-criteria Decision Making Method Multimoora. J. Multi-Crit. Decis. Anal. 2014, 21, 209-222. [CrossRef]

36. Zavadskas, E.K.; Antucheviciene, J.; Razavi Hajiagha, S.H.; Hashemi, S.S. The interval-valued intuitionistic fuzzy MultimoorA method for group decision making in engineering. Math. Probl. Eng. 2015, 2015, 560690. [CrossRef]

37. Stanujkic, D.; Karabasevic, D.; Zavadskas, E.K.; Brauers, W.K.M. An extension of the MULTIMOORA method for solving complex decision-making problems based on the use of interval-valued triangular fuzzy numbers. Transform. Bus. Econ. 2015, 14, 355-375.

38. Awasthi, A.; Baležentis, T. A hybrid approach based on BOCR and fuzzy Multimoora for logistics service provider selection. Int. J. Logist. Syst. Manag. 2017, 27, 261-282. [CrossRef]

39. Stanujkic, D.; Zavadskas, E.K.; Smarandache, F.; Brauers, W.K.M.; Karabasevic, D. A Neutrosophic Extension of the Multimoora Method. Informatica 2017, 28, 181-192. [CrossRef]

40. Zavadskas, E.K.; Baušys, R.; Juodagalvienè, B.; Garnytė-Sapranavičienè, I. Model for residential house element and material selection by neutrosophic Multimoora method. Eng. Appl. Artif. Intell. 2017, 64, 315-324. [CrossRef]

41. Gou, X.; Liao, H.; Xu, Z.; Herrera, F. Double hierarchy hesitant fuzzy linguistic term set and Multimoora method: A case of study to evaluate the implementation status of haze controlling measures. Inf. Fusion 2017, 38, 22-34. [CrossRef]

42. Ceballos, B.; Lamata, M.T.; Pelta, D.A. Fuzzy Multicriteria Decision-Making Methods: A Comparative Analysis. Int. J. Intell. Syst. 2016, 32, 722-738. [CrossRef]

43. Stević, Ž.; Pamučar, D.; Vasiljević, M.; Stojić, G.; Korica, S. Novel integrated multi-criteria model for supplier selection: Case study construction company. Symmetry (Basel) 2017, 9, 279. [CrossRef]

44. Ijadi Maghsoodi, A.; Abouhamzeh, G.; Khalilzadeh, M.; Zavadskas, E.K. Ranking and selecting the best performance appraisal method using the Multimoora approach integrated Shannon's entropy. Front. Bus. Res. China 2018, 12, 1-21. [CrossRef]

45. Ijadi Maghsoodi, A.; Kavian, A.; Khalilzadeh, M.; Brauers, W.K.M. CLUS-MCDA: A Novel Framework based on Cluster Analysis and Multiple Criteria Decision Theory in a Supplier Selection Problem. Comput. Ind. Eng. 2018, 118, 409-422. [CrossRef]

46. Hafezalkotob, A.; Hami-Dindar, A.; Rabie, N.; Hafezalkotob, A. A decision support system for agricultural machines and equipment selection: A case study on olive harvester machines. Comput. Electron. Agric. 2018, 148, 207-216. [CrossRef]

47. Chen, X.; Zhao, L.; Liang, H. A novel multi-attribute group decision-making method based on the Multimoora with linguistic evaluations. Soft Comput. 2018, 22, 5347-5361. [CrossRef]

48. Brauers, W.K.M.; Baležentis, A.; Baležentis, T. Multimoora for the EU member states updated with fuzzy number theory. Technol. Econ. Dev. Econ. 2011, 17, 259-290. [CrossRef]

49. Zadeh, L.A. Fuzzy sets. Inf. Control 1965, 8, 338-353. [CrossRef]

50. Joelianto, E.; Widiyantoro, S.; Ichsan, M. Time series estimation on earthquake events using ANFIS with mapping function. Int. J. Artif. Intell. 2009, 3, 37-63.

51. Ćirović, G.; Pamučar, D. Decision support model for prioritizing railway level crossings for safety improvements: Application of the adaptive neuro-fuzzy system. Expert Syst. Appl. 2013, 40, 2208-2223. [CrossRef]

52. Moallem, P.; Mousavi, B.S.; Naghibzadeh, S.S. Fuzzy inference system optimized by genetic algorithm for robust face and pose detection. Int. J. Artif. Intell. 2015, 13, 73-88. 
53. Nowaková, J.; Prílepok, M.; Snášel, V. Medical Image Retrieval Using Vector Quantization and Fuzzy S-tree. J. Med. Syst. 2017, 41, 18. [CrossRef] [PubMed]

54. Brauers, W.; Zavadskas, E.K. Multimoora optimization used to decide on a bank loan to buy property. Technol. Econ. Dev. Econ. 2011, 17, 174-188. [CrossRef]

55. Ijadi Maghsoodi, A.; Ijadi Maghsoodi, A.; Mosavi, A.; Rabczuk, T.; Zavadskas, E.K. Renewable Energy Technology Selection Problem Using Integrated H-SWARA-MULTIMOORA Approach. Sustainability 2018, 10, 4481. [CrossRef]

56. Wright, S. Correlation and Causation. J. Agric. Res. 1921, 20, 557-585.

57. Fox, J. An Introduction to Structural Equation Modeling With the sem Package in R. Struct. Equ. Model. 2006, 13, 465-486. [CrossRef]

58. Savalei, V.; Bentler, P.M. Structural Equation Modeling. In Handbook of Marketing Research: Uses, Misuses, and Future Advances; Sage Publications: Thousand Oaks, CA, USA, 2006; pp. 330-364.

59. Mardani, A.; Streimikiene, D.; Zavadskas, E.K.; Cavallaro, F.; Nilashi, M.; Jusoh, A.; Zare, H. Application of Structural Equation Modeling (SEM) to Solve Environmental Sustainability Problems: A Comprehensive Review and Meta-Analysis. Sustainability 2017, 9, 1814. [CrossRef]

60. Statistics Solutions. Confirmatory Factor Analysis. 2016. Available online: https://www.statisticssolutions. com/factor-analysis-sem-exploratory-factor-analysis/ (accessed on 5 December 2018).

61. Flyvbjerg, B. Five Misunderstandings About Case-Study Research. Qual. Inq. 2006, 12, 219-245. [CrossRef]

62. Cronbach, L.J.; Meehl, P.E. Conctruct validity in psychological tests. Psychol. Bull. 1955, 52, $281-302$. [CrossRef]

63. Fornell, C.; Larcker, D.F. Structural Equation Models with Unobservable Variables and Measurement Error: Algebra and Statistics. J. Mark. Res. 1981, 18, 382-388. [CrossRef]

64. Tenenhaus, M. PLS path modeling. Comput. Stat. Data Anal. 2005, 48, 159-205. [CrossRef]

65. Morente-Molinera, J.A.; Kou, G.; González-Crespo, R.; Corchado, J.M.; Herrera-Viedma, E. Solving multi-criteria group decision making problems under environments with a high number of alternatives using fuzzy ontologies and multi-granular linguistic modelling methods. Knowl.-Based Syst. 2017, 137, 54-64. [CrossRef]

66. Morente-Molinera, J.A.; Kou, G.; González-Crespo, R.; Corchado, J.M.; Managing Multi-Criteria Group. Decision Making Environments with High Number of Alternatives Using Fuzzy Ontologies. SoMeT 2018, 303, 493-506.

67. Schrepp, M.; Hinderks, A.; Thomaschewski, J. Design and Evaluation of a Short Version of the User Experience Questionnaire (UEQ-S). Int. J. Interact. Multimed. Artif. Intell. 2017, 4, 103. [CrossRef]

68. Ijadi Maghsoodi, A.; Mosavat, M.; Hafezalkotob, A.; Hafezalkotob, A. Hybrid hierarchical fuzzy group decision-making based on information axioms and BWM: Prototype design selection. Comput. Ind. Eng. 2018, in press. [CrossRef] 